\title{
Experiments on the stability of cancrinite in the system $\mathrm{Na}_{2} \mathrm{O}-\mathrm{CaO}-\mathrm{Al}_{2} \mathrm{O}_{3}-\mathrm{SiO}_{2}-\mathrm{CO}_{2}-\mathrm{H}_{2} \mathrm{O}$
}

\author{
MONA SIRBESCU*AND DAVID M. JENKINS $\dagger$
}

Department of Geological Sciences and Environmental Studies, Binghamton University, Binghamton, New York 13902-6000, U.S.A.

\begin{abstract}
The synthesis and upper thermal stability of cancrinite were investigated experimentally in the system $\mathrm{Na}_{2} \mathrm{O}-\mathrm{CaO}-\mathrm{Al}_{2} \mathrm{O}_{3}-\mathrm{SiO}_{2}-\mathrm{CO}_{2}-\mathrm{H}_{2} \mathrm{O}$ at $2 \mathrm{kbar}$ and in the presence of a mixed $\mathrm{H}_{2} \mathrm{O}-\mathrm{CO}_{2}$ fluid. Cancrinite could only be formed under water-rich conditions in this system. The breakdown of cancrinite to nepheline + calcite occurred at decreasing temperatures with increasing $X_{\mathrm{CO}_{2}}$ as expected for a dehydration reaction of the form cancrinite $=$ nepheline + calcite $+\mathrm{n}_{\mathrm{H}_{2} \mathrm{O}}$. Partial melting and the formation of melilite was observed at the highest temperatures and for the most $\mathrm{H}_{2} \mathrm{O}$-rich fluid compositions.

The molecular water content of the cancrinite formed at various $T-X_{\mathrm{CO}_{2}}$ conditions was evaluated with a combined infrared (IR)-thermogravimetry (TG) technique. Results suggest (within analytical error) a decrease in the water content of cancrinite toward the breakdown reaction and an apparently constant water content along the breakdown curve. Thermodynamic analysis combining the compositional and phase-equilibrium data from this study was performed and yielded a value of $\Delta H_{\mathrm{f}}^{0}=-14722$ $\pm 147 \mathrm{~kJ}$ and $S^{0}=981 \pm 118 \mathrm{~J} / \mathrm{K}$ at $298 \mathrm{~K}$ and 1 bar for synthetic cancrinite of the composition $\mathrm{Na}_{6} \mathrm{Ca}_{1.5}\left[\mathrm{Al}_{6} \mathrm{Si}_{6} \mathrm{O}_{24}\right]\left(\mathrm{CO}_{3}\right)_{1.5} \cdot 1.1( \pm 0.4) \mathrm{H}_{2} \mathrm{O}$. This study demonstrates the important role that water plays in controlling the stability of cancrinite in igneous and metamorphic rocks.
\end{abstract}

\section{INTRODUCTION}

\section{Cancrinite crystal chemistry}

Cancrinite-group minerals are framework aluminosilicates (feldspathoids) characterized by a network of $(\mathrm{Al}, \mathrm{Si}) \mathrm{O}_{4}$ tetrahedra having fully ordered $\mathrm{Al}$ and Si cations. Their structure consists of parallel six-membered rings of alternating $\mathrm{AlO}_{4}$ and $\mathrm{SiO}_{4}$ tetrahedra (Jarchow 1965; Grundy and Hassan 1982). The hexagonal symmetry $\left(\mathrm{Pb}_{3}\right)$ results from the stacking of these six-membered rings in an $\mathrm{ABAB}$... sequence. This stacking gives rise to large continuous channels parallel to the $6_{3}$ axis and chains of smaller undecahedral (elevenfold) cages along the threefold axes. The large channels contain extra-framework cations $\left(\mathrm{Na}^{+}, \mathrm{Ca}^{2+}, \mathrm{K}^{+}\right)$, anions $\left(\mathrm{CO}_{3}^{2-}, \mathrm{OH}^{-}\right)$, and $\mathrm{H}_{2} \mathrm{O}$ molecules whereas the undecahedral cages hold $\left[\mathrm{Na} \cdot \mathrm{H}_{2} \mathrm{O}\right]^{+}$clusters (Hassan and Grundy 1991; Hassan and Busseck 1992).

Phoenix and Nuffield (1949) defined the cancrinite group of minerals as $(\mathrm{Na}, \mathrm{K}, \mathrm{Ca}, \mathrm{Al})_{6-8}\left[\mathrm{Si}_{6} \mathrm{Al}_{6} \mathrm{O}_{24}\right]\left(\mathrm{SO}_{4}, \mathrm{CO}_{3}\right)_{1-2} \cdot 1-5 \mathrm{H}_{2} \mathrm{O}$, and proposed an ideal formula for the carbonate end-member of cancrinite as $\mathrm{Na}_{6} \mathrm{Ca}_{2}\left[\mathrm{Si}_{6} \mathrm{Al}_{6} \mathrm{O}_{24}\right]\left(\mathrm{CO}_{3}\right)_{2} \cdot 3 \mathrm{H}_{2} \mathrm{O}$. They recognized the difficulties of dealing with the chemistry of this mineral, due to numerous possible substitutions, vacant positions, and variable zeolitic water content. Given the role that the carbonate salts play in the chemistry of cancrinite, Eitel (1922),

*Present Address: Department of Geological Sciences, University of Missouri-Columbia, Columbia, Missouri 65211; E-mail: msca96@mizzou.edu

†E-mail: dmjenks@binghamton.edu
Edgar and Burley (1963), and Watkinson and Wyllie (1971) proposed phase diagrams and mineral reactions emphasizing the role of carbonates and $\mathrm{CO}_{2}$ in cancrinite phase relations without explicitly considering its water content. The present study draws attention to the role that water plays in the formation and stability of the carbonate end-member of cancrinite. The hydroxyl group is a possible constituent in both natural and synthetic cancrinites. A hydroxyl-rich (basic) cancrinite has been synthesized (e.g., Edgar 1963; Hassan and Grundy 1991) and also has been found occurring as a rare natural variety (Nadezhina et al. 1991).

The zeolitic character of the water in cancrinite was demonstrated by the continuous weight loss observed during the TG study performed by Buhl (1991), who showed that water was released in the interval $80-430^{\circ} \mathrm{C}$ for two synthetic cancrinites. At higher temperatures $\left(730-880^{\circ} \mathrm{C}\right)$, the release of water present as hydroxyl groups accompanied by the release of $\mathrm{CO}_{2}$ took place in a strong endothermic reaction. In a detailed TG and structural study, Hassan (1996) showed the complete thermal behavior of a well-characterized sample from Bancroft, Ontario, with an ideal formula expressed as $\mathrm{Na}_{6} \mathrm{Ca}_{2}\left[\mathrm{Si}_{6} \mathrm{Al}_{6} \mathrm{O}_{24}\right]\left(\mathrm{CO}_{3}\right)_{2} \cdot 2 \mathrm{H}_{2} \mathrm{O}$. The water loss continued up to $\sim 860^{\circ} \mathrm{C}$, followed by a rapid release of $\mathrm{CO}_{2}$ between 924 and $940{ }^{\circ} \mathrm{C}$. Although the overall weight loss and the exact intervals of dehydration and decarbonation might vary in different thermal studies of cancrinite because of compositional differences, the general shape of the TG and differential thermal gravimetry (DTG) curves remain the same, partitioned into two main steps for dehydration and decarbonation respectively (Buhl 1991; Hassan 1996; Barrer et al. 1970; Liu et al. 1993). 


\section{Cancrinite associations}

Numerous investigators have reported cancrinite as reaction rims between nepheline and calcite, such as in alkali gabbros from Fen, Norway (Deer et al. 1963), in nepheline syenites from the alkaline pluton at Ditrau, Romania (Sirbescu's personal observation; Streckeisen personal communication 1992), and in ijolites from Homa Bay, Kenya (Pulfrey 1949). Poikilitic inclusions of calcite in nepheline are commonly rimmed by cancrinite and sodalite in nepheline syenites from Siberia (Sobolev et al. 1974). However, not all calcite in contact with nepheline has a rim of cancrinite, suggesting either that the introduction of calcite occurred at various stages during the thermal history of the rock or that the $\mathrm{H}_{2} \mathrm{O} / \mathrm{CO}_{2}$ ratio of the ambient fluid influenced the formation of cancrinite. Similarly, numerous nepheline syenite pegmatites display cancrinite as nests and veinlets in nepheline (e.g., Ilmen Mts: Deer et al. 1963), or as individual crystals, without any obvious relationship to nepheline or calcite (e.g., Ditrau alkaline pluton: Constantinescu and Anastasiu 1979).

A temperature range of $750-900{ }^{\circ} \mathrm{C}$ was calculated for cancrinite-bearing phonolites from the Marangudzi, Zimbabwe, alkaline ring complex (Henderson and Ezepue 1989), based on nepheline-alkali-feldspar thermometry (Hamilton 1961) at a total pressure of $1 \mathrm{kbar}$ with variable water content. A primary fluid inclusion homogenization study of cancrinite crystals from a ditroite in the Synnyr pluton, Siberia, generated a temperature of $630^{\circ} \mathrm{C}$, at pressures of $1.1-1.5 \mathrm{kbar}$ (Sobolev et al. 1974). Primary fluid inclusions in various cancrinite-bearing nepheline syenites studied by Sobolev et al. (1974) are mainly $\mathrm{CO}_{2}-\mathrm{H}_{2} \mathrm{O}$ mixtures.

Whether crystallized from a magma or from a subsolidus reaction involving nepheline and calcite, cancrinite stability appears to be strongly dependent on the presence of water.

\section{Previous experimental work}

Previous experimental work on cancrinite or cancrinite-like compounds has been conducted mostly under hydrothermal conditions, suggesting that water is an important constituent in cancrinite formation. However, in the pioneering study of Eitel $(1922,1954)$ on the binary system calcite-nepheline, cancrinite, seen as a double-salt compound $\left(3 \mathrm{NaAlSiO}_{4} \cdot \mathrm{CaCO}_{3}\right)$, appears to have melted incongruently at a temperature of $1253^{\circ} \mathrm{C}$ under a carbon dioxide atmosphere of about $0.11 \mathrm{kbar}$. A closer look at the description of the experimental apparatus used by Eitel (1922) raises doubts about the purity of the $\mathrm{CO}_{2}$ atmosphere. To produce $\mathrm{CO}_{2}$ pressures up to $0.10-0.11 \mathrm{kbar}$, Eitel (1922) used a container filled with carbonic acid that was linked to the high-temperature oven, so that thermal decomposition of $\mathrm{H}_{2} \mathrm{CO}_{3}$ took place at temperatures exceeding the critical point of $\mathrm{CO}_{2}$. Eitel (1922) does not, however, mention addition of any device to purify the generated $\mathrm{CO}_{2}$ atmosphere, so that one can suppose that the melting reaction took place in a mixed volatile $\mathrm{H}_{2} \mathrm{O}-\mathrm{CO}_{2}$ atmosphere.

Several cancrinite synthesis studies are summarized in Table 1. Watkinson (1965) and Watkinson and Wyllie (1971) encountered cancrinite as a spontaneously nucleated phase in their studies on carbonatites and alkaline igneous rocks. The section nepheline-calcite- $(25 \mathrm{wt} \%) \mathrm{H}_{2} \mathrm{O}$ at $P_{\mathrm{CO}_{2}}=1$ kbar yielded various combinations of cancrinite, nepheline, calcite, a compound with sodalite-type structure (hydroxy-haüyne, considered as a high-temperature polymorph of cancrinite) and a $\mathrm{Na}-\mathrm{Ca}$ melilite, at different temperatures. The bulk composition of 81 wt $\%$ nepheline and $19 \mathrm{wt} \%$ calcite corresponds to the assumed composition of carbonate cancrinite $\left(3 \mathrm{NaAlSiO}_{4} \cdot \mathrm{CaCO}_{3}\right.$, Eitel 1922). None of these phases were chemically analyzed, so that the water content was not determined directly. Although Watkinson (1965) specified the necessity of performing some investigations of the nepheline-calcite-water system under variable $X_{\mathrm{CO}_{2}}$ conditions, such experiments have not been performed to our knowledge. Edgar and Burley (1963) and Edgar (1963) synthesized various cancrinites in hydrothermal conditions but did not investigate the upper thermal stability of the calcium-carbonate cancrinite above $800^{\circ} \mathrm{C}$. Edgar (1963) noticed that cancrinite with the ideal structural formula $\mathrm{Na}_{6} \mathrm{Ca}_{2}\left[\mathrm{Al}_{6} \mathrm{Si}_{6} \mathrm{O}_{24}\right]\left(\mathrm{CO}_{3}\right)_{2} \cdot \mathrm{nH}_{2} \mathrm{O}$ formed as a product of reaction between nepheline, calcite, and water. Hydrothermal (pure $\mathrm{H}_{2} \mathrm{O}$ ) investigations of the reaction:

$$
\text { cancrinite }=6 \text { nepheline }+2 \text { calcite }+\mathrm{nH}_{2} \mathrm{O}
$$

were performed by Edgar (1963) in the range of 750 to $1000^{\circ} \mathrm{C}$ and 0.9 to $3 \mathrm{kbar}$. Equilibrium relationships were complicated by the spontaneous and apparently inconsistent nucleation of the extra phases Na-rich melilite and a haüyne-group mineral.

The purpose of this study was: (1) to synthesize and characterize the calcium-carbonate cancrinite having the ideal formula of $6 \mathrm{NaAlSiO}_{4} \cdot 2 \mathrm{CaCO}_{3} \cdot \mathrm{nH}_{2} \mathrm{O}$; (2) to investigate its upper thermal stability in a mixed-volatile $\mathrm{H}_{2} \mathrm{O}-\mathrm{CO}_{2}$ fluid at $2 \mathrm{kbar}$; and (3) to evaluate its thermodynamic properties based on the univariant boundary for reaction 1 in $T-X_{\mathrm{CO}_{2}}$ space. Reversals of reaction 1 were obtained without interference of other phases over a large $T-X_{\mathrm{CO}_{2}}$ interval. The water content of cancrinite at equilibrium conditions was determined through a combination of IR and TG measurements.

\section{EXPERIMENTAL TECHNIQUES}

\section{Apparatus}

One-atmosphere syntheses were performed in a muffle furnace in a Pt crucible. High-pressure experiments were performed in either horizontally mounted cold-seal vessels constructed of René 41 (with filler rods) or in internally heated gas vessels. For the cold-seal vessels, water was used as the pressure medium. Pressure was monitored using bourdon-tube gauges calibrated against a factory-calibrated Heise bourdon-tube gauge and is considered to be accurate to within \pm 50 bar. Temperatures were measured in external thermocouple wells using chromelalumel thermocouples, calibrated against the freezing points of $\mathrm{Sn}\left(231.9^{\circ} \mathrm{C}\right)$ and $\mathrm{NaCl}\left(800.5^{\circ} \mathrm{C}\right)$, and are considered accurate to within $\pm 10^{\circ} \mathrm{C}$. Phase-equilibrium experiments were performed in internally heated gas vessels using Ar as the pressure medium (Holloway 1971). Pressures were monitored with both a bourdon tube gauge and a factory calibrated (Harwood Engineering) manganin cell and are believed accurate to \pm 50 bar. Temperatures and temperature gradients along the sample 
TABLE 1. Synthetic cancrinites reported in the literature

\begin{tabular}{|c|c|c|c|c|}
\hline $\begin{array}{l}\text { Chemical composition and name } \\
\end{array}$ & $a(\AA)$ & $c(\AA)$ & Conditions of synthesis & Reference \\
\hline $\mathrm{Na}_{8}\left[\mathrm{Al}_{6} \mathrm{Si}_{6} \mathrm{O}_{24}\right]\left(\mathrm{CO}_{3}\right) \cdot 3 \mathrm{H}_{2} \mathrm{O}$ (ideal) & 12.57 & 5.13 & hydrothermal methods & Nithollon (1955) \\
\hline "3 $\mathrm{NaAISiO}{ }_{4} \cdot \mathrm{Na}_{2} \mathrm{CO}_{3}$ " natrodavyne & $12.69(2)$ & $5.18(2)$ & $\begin{array}{l}T=500-600{ }^{\circ} \mathrm{C}, \\
P_{\mathrm{H}_{2} \mathrm{O}}=0.7 \text { to } 2.1 \mathrm{kbar}\end{array}$ & Edgar and Burley (1963) \\
\hline 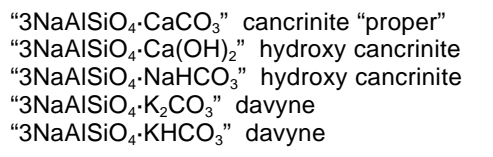 & $\begin{array}{l}12.59(2) \\
12.60(2) \\
12.67(2) \\
12.73(2) \\
12.73(2)\end{array}$ & $\begin{array}{l}5.17(2) \\
5.14(2) \\
5.16(2) \\
5.18(2) \\
5.20(2)\end{array}$ & $\begin{array}{l}T>800{ }^{\circ} \mathrm{C}, P_{\mathrm{H}_{2} \mathrm{O}}=1.38 \mathrm{kbar} \\
T>800^{\circ} \mathrm{C}, P_{\mathrm{H}_{2} \mathrm{O}}=1.38 \mathrm{kbar} \\
T<600{ }^{\circ} \mathrm{C}, P_{\mathrm{H}_{2} \mathrm{O}}=1.38 \mathrm{kbar} \\
T<450-500{ }^{\circ} \mathrm{C}, P_{\mathrm{H}_{2} \mathrm{O}}=1.38 \mathrm{kbar} \\
T<450-500^{\circ} \mathrm{C}, P_{\mathrm{H}_{2} \mathrm{O}}=1.38 \mathrm{kbar}\end{array}$ & Edgar (1963) \\
\hline $\mathrm{Na}_{7} \mathrm{Ca}_{0.9}\left[\mathrm{Al}_{6} \mathrm{Si}_{6} \mathrm{O}_{24}\right]\left(\mathrm{CO}_{3}\right)_{1.4} \cdot 2.1 \mathrm{H}_{2} \mathrm{O}$ & $12.63(5)$ & $5.11(3)$ & hydrothermal methods & Smolin et al. (1981) \\
\hline $\mathrm{Na}_{7.6} \mathrm{Ca}_{0.4}\left[\mathrm{Al}_{6} \mathrm{Si}_{6} \mathrm{O}_{24}\right](\mathrm{OH})_{0.2}\left(\mathrm{CO}_{3}\right) \cdot 2 \mathrm{H}_{2} \mathrm{O}$ & 12.62(1) & $5.14(2)$ & hydrothermal methods & Emiraliev and Yamzin (1982) \\
\hline $\begin{array}{l}\mathrm{Na}_{8}\left[\mathrm{Al}_{6} \mathrm{Si}_{6} \mathrm{O}_{24}\right](\mathrm{OH})_{2} \cdot 2.8 \mathrm{H}_{2} \mathrm{O} \\
\mathrm{Na}_{8}\left[\mathrm{Si}_{6} \mathrm{Al}_{6} \mathrm{O}_{24}\right](\mathrm{OH})_{2} \cdot 3 \mathrm{H}_{2} \mathrm{O} \text { (ideal) }\end{array}$ & $12.664(2)$ & $5.159(1)$ & $T=450^{\circ} \mathrm{C}, P_{\mathrm{H}_{2} \mathrm{O}}=1 \mathrm{~kb}$ & Hassan and Grundy (1991) \\
\hline $\begin{array}{l}\mathrm{Na}_{7.84}\left[\mathrm{Al}_{6} \mathrm{Si}_{6} \mathrm{O}_{24}\right] \cdot 5.98\left(\mathrm{H}_{2} \mathrm{O}, \mathrm{OH}\right) \\
\mathrm{Na}_{7.5}\left[\mathrm{Al}_{6} \mathrm{Si}_{6} \mathrm{O}_{24}\right](\mathrm{OH})_{1.5} \cdot 5 \mathrm{H}_{2} \mathrm{O} \text { (ideal) }\end{array}$ & 12.68 & 5.18 & - & Bresciani Pahor et al. (1982) \\
\hline $\mathrm{Na}_{8}\left[\mathrm{Si}_{6} \mathrm{Al}_{6} \mathrm{O}_{24}\right](\mathrm{OH})_{2} \cdot 5 \mathrm{H}_{2} \mathrm{O}$ (ideal) & 12.74 & 5.19 & hydrothermal methods & Klaska et al. (1979) \\
\hline $\mathrm{Na}_{8}\left[\mathrm{Al}_{6} \mathrm{Si}_{6} \mathrm{O}_{24}\right] \mathrm{CO}_{3} \cdot 4 \mathrm{H}_{2} \mathrm{O}$ & $12.67(2)$ & $5.16(3)$ & $\begin{array}{l}\text { autoclaves, kaolinite }+\mathrm{NaOH}+ \\
\mathrm{NaHCO}_{3}, T=127^{\circ} \mathrm{C}, P=0.1 \mathrm{kbar}\end{array}$ & Buhl (1991) \\
\hline $\mathrm{Na}_{8}\left[\mathrm{Al}_{6} \mathrm{Si}_{6} \mathrm{O}_{24}\right](\mathrm{OH})_{0.3}\left(\mathrm{CO}_{3}\right)_{0.85} \cdot 3.7 \mathrm{H}_{2} \mathrm{O}$ & $12.65(1)$ & $5.15(2)$ & $\begin{array}{l}\text { autoclaves, kaolinite }+\mathrm{NaOH}+ \\
\mathrm{NaHCO}_{3}, T=500^{\circ} \mathrm{C}, P=1.5 \mathrm{kbar}\end{array}$ & Buhl (1991) \\
\hline $\mathrm{Na}_{8}\left[\mathrm{Al}_{6} \mathrm{Si}_{6} \mathrm{O}_{24}\right] \mathrm{CO}_{3} \cdot 3 \mathrm{H}_{2} \mathrm{O}$ & $12.66(1)$ & $5.16(1)$ & $\begin{array}{l}\text { autoclaves, kaolinite }+\mathrm{NaOH}+ \\
\mathrm{Na}_{2} \mathrm{CO}_{3}, T=500^{\circ} \mathrm{C}, P=1.5 \mathrm{kbar}\end{array}$ & Hermeler et al. (1991) \\
\hline $\begin{array}{l}\mathrm{Na}_{6}\left[\mathrm{Al}_{6} \mathrm{Si}_{6} \mathrm{O}_{24}\right] 1.08 \mathrm{SiO}_{2} 0.57 \mathrm{Na}_{2} \mathrm{O} \cdot 4.05 \mathrm{H}_{2} \mathrm{O} \\
\text { basic cancrinite }\end{array}$ & $12.72(2)$ & $5.19(1)$ & $\begin{array}{l}\text { from gel, excess } \mathrm{NaOH}, \\
T=390^{\circ} \mathrm{C}\end{array}$ & Barrer et al. (1970) \\
\hline $\begin{array}{l}\text { nitrate cancrinite } \\
\text { chromate cancrinite } \\
\text { molybdate cancrinite }\end{array}$ & $\begin{array}{l}12.67(2) \\
12.72(2) \\
12.75(2)\end{array}$ & $\begin{array}{l}5.19(1) \\
5.19(1) \\
5.19(1)\end{array}$ & from kaolinite $+\mathrm{NaOH}+$ salts & Barrer et al. (1970) \\
\hline $\begin{array}{l}\mathrm{Na}_{8}\left[\mathrm{Al}_{6} \mathrm{Ge}_{6} \mathrm{O}_{24}\right] \mathrm{Ge}(\mathrm{OH})_{6} \cdot 2 \mathrm{H}_{2} \mathrm{O} \\
\text { germanate cancrinite }\end{array}$ & 12.75 & 5.14 & - & Belokoneva et al. (1985) \\
\hline
\end{tabular}

capsule were measured by two inconel-sheathed, chromel-alumel thermocouples situated at either end of the capsule. The arrangement of capsule and thermocouples was packed with silica wool in a copper cylinder to reduce the thermal gradients (Jenkins and Clare 1990). Both thermocouples were calibrated periodically against the freezing points of $\mathrm{LiCl}\left(605{ }^{\circ} \mathrm{C}\right)$ and $\mathrm{NaCl}(800.5$ ${ }^{\circ} \mathrm{C}$ ) and are considered to be accurate to within $\pm 2{ }^{\circ} \mathrm{C}$. Temperature differences across the samples ranged from 2 to $20^{\circ} \mathrm{C}$. In the calculation of the boundary, all experiments with a temperature difference higher than $8^{\circ} \mathrm{C}$ have been eliminated.

\section{Phase synthesis}

All phases were made from reagent-grade oxides and carbonates. These included $\mathrm{SiO}_{2}$, which was made by desiccating silicic acid (Fisher Scientific) in air at $1000{ }^{\circ} \mathrm{C}$ for several days, $\mathrm{Al}_{2} \mathrm{O}_{3}$ (Aldrich Chemicals), $\mathrm{Na}_{2} \mathrm{CO}_{3}$ (Fisher Scientific) as a source of $\mathrm{Na}_{2} \mathrm{O}$, which was preheated at $\sim 370{ }^{\circ} \mathrm{C}$ for several hours to drive off absorbed water, and $\mathrm{CaCO}_{3}$ (Fisher Scientific). Stoichiometric mixtures of the appropriate oxides and carbonates were thoroughly ground together in an agate mortar under acetone for about 1/2 hour.

Nepheline synthesis was performed in two steps. First, an oxide/carbonate mixture was heated in air, initially at 950 $1000{ }^{\circ} \mathrm{C}$ to drive off $\mathrm{CO}_{2}$ and subsequently at $850{ }^{\circ} \mathrm{C}$ for $3-4$ cycles of 5-7 day duration with intermittent grinding until the X-ray diffraction (XRD) patterns were devoid of corundum. Secondly, around $170 \mathrm{mg}$ of material was sealed with distilled $\mathrm{H}_{2} \mathrm{O}(20 \mathrm{wt} \%)$ in a Pt capsule and treated hydrothermally at 2 kbars and $800{ }^{\circ} \mathrm{C}$ for four days. The purity of the product was confirmed by optical microscopy and XRD. Small differences were noted between the XRD pattern of nepheline treated hydrothermally and that made at $1 \mathrm{~atm}$. The hydrothermally treated nepheline had three additional peaks in the XRD pattern with intensities ( $<5 \%$ visually) at $22.70^{\circ}, 28.15^{\circ}$, and $31.5^{\circ} 2 \theta$, some variations in the intensities of the major peaks, and, microscopically, the appearance of simple and lamellar twinning for the majority of the large, euhedral crystals. These features were not seen in the 1-atm synthesis, but previously had been identified in synthetic sub-potasic nepheline (type-B) by Henderson and Roux (1977) who attributed these to pseudohexagonal domains, stable only below a low-temperature, displacive inversion. The same results (pure nepheline type-B) were obtained when nepheline was synthesized in hydrothermal conditions $\left(2 \mathrm{kbar}\right.$ water pressure and $800{ }^{\circ} \mathrm{C}$ ) directly from the oxides. Use of this nepheline as starting material should not affect the results studied in a temperature range of $750-960{ }^{\circ} \mathrm{C}$, because the displacive inversion back to a hexagonal structure takes place at only $190^{\circ} \mathrm{C}$ (Henderson and Roux 1977). 
Calcite was made by annealing the reagent calcium carbonate at $\sim 400{ }^{\circ} \mathrm{C}$ to drive off all moisture and to improve crystallinity.

Attempts to synthesize cancrinite under dry conditions at 850-1050 ${ }^{\circ} \mathrm{C}$ and $4 \mathrm{kbar}$ were unsuccessful. Synthesis of cancrinite was successful only under hydrothermal conditions. Cancrinite was made from nepheline and $\mathrm{CaCO}_{3}$ mixed in the proportion of $3: 1$ in the presence of $\sim 15 \% \mathrm{H}_{2} \mathrm{O}$ at the conditions listed in Table 2. Cancrinite made in experiments can2-2, can3-1, and can5-1 (Table 2) was considered sufficiently pure and further used as a starting material in the investigation of cancrinite breakdown reaction. Sample can4-1 was found to contain $\sim 10 \%$ (vol) of Na-rich melilite and was not used as a

TABLE 2. Conditions for synthesis of cancrinite in this study

\begin{tabular}{|c|c|c|c|c|c|}
\hline Synthesis code & Starting material & $T,{ }^{\circ} \mathrm{C}^{*}$ & $P$, kbar & $t$, days & Result \\
\hline can2-2† & ne1-4+ $\mathrm{Cc}+\mathrm{H}_{2} \mathrm{O}$ & $750(5)$ & 2.20 & 5.00 & can + cc (trace, $<2 \%)$ \\
\hline can3-1 & ne $3-4+\mathrm{Cc}+\mathrm{H}_{2} \mathrm{O}$ & $760(10)$ & 2.20 & 7.00 & can + cc (trace) \\
\hline can4-1†‡ & ne3-4+ $\mathrm{Cc}+\mathrm{H}_{2} \mathrm{O}$ & $780(5)$ & 2.05 & 13.00 & $\mathrm{can}+\mathrm{mel}(10 \%)$ \\
\hline can5-1‡ & $\begin{array}{c}\text { ne3-4+CC }+\mathrm{H}_{2} \mathrm{O}+\mathrm{CO}_{2} \\
\left(X_{\mathrm{CO}_{2}}=0.45\right)\end{array}$ & $775(5)$ & 2.15 & 10.00 & can + cc (trace) \\
\hline
\end{tabular}

Note: Abbreviations are: $c a n=$ cancrinite $;$ ne $=$ nepheline $; c c=$ calcite $;$ mel = melilite .

* Uncertainty in last digit shown in parentheses.

† TGA and IR analyses were performed.

¥ Microprobe analyses were performed.

TABLE 3. Experimental results for reaction 1 in the text.

\begin{tabular}{|c|c|c|c|c|c|c|c|}
\hline $\begin{array}{l}\text { Run } \\
\text { code }\end{array}$ & $T,{ }^{\circ} \mathrm{C}^{*}$ & $X_{\mathrm{CO}_{2}}^{\text {in }}$ & $X_{\mathrm{CO}_{2}}^{\text {out }}$ & $X_{\mathrm{CO}_{2}}^{\text {avg }}$ & $t, \mathrm{~h}$ & Mineral assemblage & $\begin{array}{l}\text { Reaction } \\
\text { direction }\end{array}$ \\
\hline 2 & $1000(7)$ & 0.00 & - & - & 50 & $\mathrm{~L}$ & $(-)$ \\
\hline 3 & $958(3)$ & 0.00 & - & - & 58 & $\mathrm{ne}+\mathrm{cc}+\mathrm{mel}+\mathrm{L}$ & $(-)$ \\
\hline 6 & $935(4)$ & 0.00 & - & - & 64 & $\mathrm{ne}+\mathrm{cc}+\mathrm{mel}+\mathrm{L}$ & $(-)$ \\
\hline 10 & $953(2)$ & 0.00 & - & - & 67 & $n e+c c+m e l+(c a n)+L$ & $(-)$ \\
\hline 12 & $917(2)$ & 0.00 & - & - & 75 & $\mathrm{can}+\mathrm{mel}$ & $(+)$ \\
\hline 11 & $924(5)$ & 0.00 & - & - & 45 & $\mathrm{can}+\mathrm{mel}+(\mathrm{ne}+\mathrm{cc})+\mathrm{L}$ & $(+)$ \\
\hline 39 & $802(2)$ & 0.00 & 0.01 & 0.01 & 77 & can + mel & + \\
\hline $40 \dagger$ & $802(3)$ & 0.25 & 0.26 & 0.25 & 86 & $\mathrm{can}+\mathrm{cc}$ & + \\
\hline $41 \ddagger$ & $804(4)$ & 0.68 & 0.71 & 0.70 & 72 & $\mathrm{ne}+\mathrm{cc}+\mathrm{can}$ & - \\
\hline $42 \dagger$ & $811(8)$ & 0.51 & 0.54 & 0.53 & 65 & can $+(\mathrm{cc})$ & + \\
\hline 43 & $801(3)$ & 0.89 & 0.91 & 0.90 & 65 & ne $+c c+$ ha & - \\
\hline 44†‡ & $750(4)$ & 0.71 & 0.75 & 0.73 & 65 & $c a n+n e+c c$ & + \\
\hline $45 \dagger$ & $751(4)$ & 0.51 & 0.55 & 0.53 & 71 & can + (cc) & + \\
\hline 46†‡ & $850(2)$ & 0.60 & 0.64 & 0.62 & 164 & $c a n+n e+c c$ & + \\
\hline $47 \dagger$ & $849(4)$ & 0.51 & 0.59 & 0.55 & 113 & $\mathrm{can}+\mathrm{cc}$ & + \\
\hline $48 \ddagger$ & $798(2)$ & 0.69 & 0.74 & 0.72 & 113 & can + ne + cc & + \\
\hline $49 \dagger$ & $878(2)$ & 0.50 & 0.48 & 0.49 & 124 & can $+(\mathrm{cc})$ & + \\
\hline 50 & $848(2)$ & 0.74 & 0.77 & 0.75 & 86 & $\mathrm{ne}+\mathrm{cc}$ & - \\
\hline 51 & $884(4)$ & 0.55 & $?$ & 0.55 & 70 & $\mathrm{can}+(\mathrm{ne}+\mathrm{cc})$ & + \\
\hline $52 \ddagger$ & $880(3)$ & 0.63 & 0.57 & 0.60 & 117 & $\mathrm{can}+\mathrm{ne}+\mathrm{cc}$ & + \\
\hline $53 \neq \S$ & $900(2)$ & 0.57 & 0.58 & 0.58 & 50 & $\mathrm{ne}+\mathrm{cc}+\mathrm{can}$ & - \\
\hline $54 † \ddagger$ & $900(2)$ & 0.53 & 0.54 & 0.54 & 72 & $\mathrm{can}+\mathrm{ne}+\mathrm{cc}$ & + \\
\hline $55 \dagger \ddagger \S$ & $920(4)$ & 0.51 & 0.47 & 0.49 & 48 & can + ne $+c c$ & $\mathrm{nr}$ \\
\hline $56 † \ddagger$ & 918(2) & 0.48 & 0.50 & 0.49 & 116 & $c a n+n e+c c$ & + \\
\hline $57 \ddagger$ & 918(2) & 0.53 & 0.53 & 0.53 & 45 & $\mathrm{ne}+\mathrm{cc}+\mathrm{can}$ & - \\
\hline $58 \neq \S$ & $931(2)$ & 0.48 & 0.46 & 0.47 & 115 & $\mathrm{can}+\mathrm{ne}+\mathrm{cc}$ & + \\
\hline 59 & $930(2)$ & 0.52 & $?$ & 0.52 & 43 & $\mathrm{ne}+\mathrm{cc}+\mathrm{can}$ & - \\
\hline $60 \ddagger$ & $931(2)$ & 0.47 & 0.47 & 0.47 & 92 & $\mathrm{ne}+\mathrm{cc}+\mathrm{can}$ & - \\
\hline 61 & $951(2)$ & 0.38 & 0.37 & 0.38 & 47 & $n e+c c+c a n$ & - \\
\hline $62 † \ddagger \S$ & $942(2)$ & 0.39 & 0.39 & 0.39 & 94 & $c a n+n e+c c$ & $\mathrm{nr}$ \\
\hline 63 & $960(3)$ & 0.21 & 0.19 & 0.20 & 62 & $n e+c c+(c a n)+L$ & - \\
\hline $64 † \ddagger$ & $940(2)$ & 0.21 & 0.22 & 0.22 & 47 & $\mathrm{can}+(\mathrm{mel})+(\mathrm{ne}+\mathrm{cc})$ & + \\
\hline 65 & $951(2)$ & 0.22 & 0.21 & 0.22 & 93 & $\mathrm{ne}+\mathrm{cc}+\mathrm{mel}+\mathrm{L}$ & - \\
\hline $66 \ddagger$ & $945(2)$ & 0.31 & $?$ & 0.31 & 90 & $\mathrm{can}+\mathrm{ne}+\mathrm{cc}$ & + \\
\hline $67 \dagger \ddagger$ & $951(2)$ & 0.31 & 0.31 & 0.31 & 70 & $\mathrm{can}+\mathrm{ne}+\mathrm{cc}$ & $\mathrm{nr}$ \\
\hline 68 & $947(4)$ & 0.25 & 0.22 & 0.24 & 72 & $c a n+n e+c c+L$ & + \\
\hline $69 \dagger$ & $848(3)$ & 0.64 & 0.65 & 0.65 & 142 & $\mathrm{can}+\mathrm{ne}+\mathrm{cc}$ & $\mathrm{nr}$ \\
\hline $70 † \ddagger$ & $848(2)$ & 0.63 & 0.63 & 0.63 & 97 & $\mathrm{can}+\mathrm{ne}+\mathrm{cc}$ & + \\
\hline $71 \neq$ & $847(2)$ & 0.65 & 0.67 & 0.66 & 144 & $c a n+n e+c c$ & $\mathrm{nr}$ \\
\hline 73 & $850(3)$ & 0.67 & 0.69 & 0.68 & 71 & $\mathrm{ne}+\mathrm{cc}+\mathrm{can}$ & - \\
\hline $74 \ddagger$ & $799(4)$ & 0.71 & 0.72 & 0.72 & 171 & $\mathrm{ne}+\mathrm{cc}+\mathrm{can}$ & - \\
\hline $75 \ddagger$ & $796(7)$ & 0.70 & 0.70 & 0.69 & 127 & $\mathrm{can}+\mathrm{ne}+\mathrm{cc}$ & + \\
\hline $76 \ddagger$ & $750(2)$ & 0.76 & 0.75 & 0.75 & 336 & $\mathrm{ne}+\mathrm{cc}+(\mathrm{can})$ & - \\
\hline
\end{tabular}

Notes: Pressure $=2$ kbar. $X_{\mathrm{CO}}$ in is the mole fraction of $\mathrm{CO}_{2}$ at the beginning of the experiment; $X_{\mathrm{CO}}$ out is the mole fraction of $\mathrm{CO}_{2}$ measured at the end of the experiment; $X_{\mathrm{CO}_{2}}^{\text {avg }}$ is the average of $X_{\mathrm{CO}_{2}}^{\text {in }}$ and $X_{\mathrm{CO}_{2}^{\text {out }}}$. The direction of reaction is indicated by: "+" = growth of cancrinite relative to nepheline; "-" = breakdown of cancrinite; "(+)" or "(-)" = growth or breakdown of cancrinite along the metastable extension of reaction (1); and "nr" = no reaction observed. Abbreviations: ha = haüyne; remainder same as Table 2.

* Uncertainty in last digit shown in parentheses.

† IR analysis was performed.

‡ Data used in thermodynamic analysis.

$\S$ Microprobe analysis was performed. 
starting material. However, the texture of can4-1, with very large $(0.1-0.5 \mathrm{~mm})$ euhedral "porphyroblasts" of melilite and fine-grained cancrinite crystals of only $0.01-0.05 \mathrm{~mm}$, permitted manual separation of pure melilite and relatively pure cancrinite by hand-picking and sieving. These concentrates were used for physical investigations of both cancrinite and melilite. The stability of melilite at the conditions of run can4-1 has been confirmed by further experiments (Table 3). The absence of melilite in can2-2 and can3-1 could be explained by the higher pressures and lower temperatures than in can4-1. In run can5-1 (Table 2) a mixed-volatile atmosphere was used to eliminate melilite.

\section{Investigation of cancrinite breakdown reaction}

The investigation of cancrinite breakdown (reaction 1) was conducted using starting mixtures of the synthetic nepheline, cancrinite (presumed to be $\mathrm{Na}_{6} \mathrm{Ca}_{2}\left[\mathrm{Al}_{6} \mathrm{Si}_{6} \mathrm{O}_{24}\right]\left(\mathrm{CO}_{3}\right)_{2} \cdot 2 \mathrm{H}_{2} \mathrm{O}$ ), and calcite in proportions corresponding to the stoichiometry of the reaction. Portions of the starting mixtures were loaded into $\mathrm{Pt}$ capsules. Nominally anhydrous oxalic acid $\left(\mathrm{C}_{2} \mathrm{H}_{2} \mathrm{O}_{4} \cdot 0.23 \mathrm{H}_{2} \mathrm{O}\right.$, water content by gravimetric analysis) and distilled-deionized water were added to obtain the desired mole fraction of $\mathrm{CO}_{2}$ and also to preserve a mineral:fluid proportion of $\sim 1: 1$ by weight.

Fluid compositions were prepared and determined using a semi-micro balance (Mettler-Toledo, model AG245) with a precision of $0.01 \mathrm{mg}$. Maximum uncertainties in preparation of the fluid mixtures amounted to an estimated error of 0.005 $X_{\mathrm{CO}_{2}}$. The amount of $\mathrm{CO}_{2}$ gas in the capsule was measured after each experiment by piercing the capsule and measuring the mass loss. The capsule was wrapped with a paper wipe prior to piercing to capture any expelled $\mathrm{H}_{2} \mathrm{O}$. Measurement of $\mathrm{H}_{2} \mathrm{O}$ was determined by summing up the amount of water absorbed by the paper, assuming that all water escaped during $\mathrm{CO}_{2}$ eruption was retained in the paper, and the mass lost by the pierced capsule after heating at $110{ }^{\circ} \mathrm{C}$ for 15 minutes. The water content of the oxalic acid limited the maximum theoretical $X_{\mathrm{CO}_{2}}$ to 0.897 . The minimum $X_{\mathrm{CO}_{2}}$ was found to be 0.012 at $800{ }^{\circ} \mathrm{C}$ for an intended $X_{\mathrm{CO}_{2}}$ of 0 (no oxalic acid added), presumably due to calcite solubility in the aqueous fluid. However, this value is much higher than the solubility of calcite at the same $P$ - $T$ conditions (Fein and Walther 1987). The enhanced solubility tentatively is attributed to a greater extent of carbonate or bi-carbonate anion complexing occurring in this more chemically complex system.

The $X_{\mathrm{CO}_{2}}$ values reported in this study are given mainly by the input amounts of $\mathrm{H}_{2} \mathrm{O}$ and oxalic acid. Variations in the value of $X_{\mathrm{CO}_{2}}$ caused by mineral reactions (e.g., dehydration or formation of cancrinite) were calculated to be relatively small, typically $\leq 0.06$, due to the high proportion of fluid compared to solid in the starting materials. The calculated maximum deviation in $X_{\mathrm{CO} 2}$ for samples in which reaction 1 ran completely to the left or to the right is similar to the estimated errors of the weighing and piercing technique. There is no obvious correlation between the sign of the observed deviation and the mineral composition of the run product, nor any other variables ( $T$ or intended $\left.X_{\mathrm{CO}_{2}}\right)$. A cumulative value of analytical uncertainty in $X_{\mathrm{CO}_{2}}$ due to errors in the weighing technique is averaged as $\pm\left(\Sigma\left|X_{\mathrm{CO}_{2}}{ }^{\text {in }}-X_{\mathrm{CO}_{2}}{ }_{\text {out }}\right|\right) / \mathrm{N}= \pm 0.019$, where $X_{\mathrm{CO} 2}^{\text {in }}$ represents the intended value of $X_{\mathrm{CO}_{2}}, X_{\mathrm{CO}_{2}}^{\text {out }}$ represents the measured $\mathrm{X}_{\mathrm{CO}_{2}}$ after run quenching, and $\mathrm{N}=34$ is the number of runs (Table 3).

\section{Analytical techniques}

The charges were studied under the petrographic microscope using an oil of refractive index 1.530 , which is intermediate between the refractive index of cancrinite (1.500 to 1.522) and nepheline (1.534 to 1.537). This allowed rapid recognition of the main crystalline phases, even when present in very small proportions. Indices of refraction were determined using certified immersion oils.

$\mathrm{X}$-ray powder diffractograms were obtained routinely for all run products using $\mathrm{Cu} K \alpha$ radiation in the range of $17-40^{\circ} 2 \theta$. Variations in the main XRD peak heights offered a clear indication of the direction and magnitude of reaction, with departures of only $0.04 \mathrm{X}_{\mathrm{CO}_{2}}$ at $900{ }^{\circ} \mathrm{C}$ (run duration 3 days ) from the univariant boundary producing an obvious change in the major XRD peak ratios. Unit-cell refinements were performed using the computer program of Appleman and Evans (1973).

Chemical analyses were obtained by wavelength dispersive spectrometry (WDS) using a JEOL JXA-8900L microprobe. Determination of X-ray counts vs. time revealed a dramatic drop in Na X-rays with time for cancrinite under all investigated operating conditions. This diffusive loss of Na under the electron beam was found to be much more pronounced for cancrinite than for the anhydrous phases nepheline and melilite. In accord with the study of hydrous alkali glasses by Morgan and London (1996), we found that operating the microprobe at $15 \mathrm{kV}$ and $2 \mathrm{nA}$ and using counting times of only 3 seconds with a spot size of $\sim 2 \mu \mathrm{m}$ (necessitated by the small grain sizes) minimized the diffusive loss of $\mathrm{Na}$ and the concomitant "increase" of $\mathrm{Al}, \mathrm{Si}$, and $\mathrm{Ca}$. The standards used in this study were albite for $\mathrm{Na}$, diopside for $\mathrm{Ca}$ and $\mathrm{Si}$, and kyanite for $\mathrm{Al}$. The grain sizes $(20-50 \mu \mathrm{m}$ in diameter) permitted the use of conventional epoxy-mount and sample polishing techniques.

Several samples were also analyzed for their water and carbonate contents by thermo-gravimetric analysis (TG) and infrared (IR) spectroscopy. Computer-automated TG was performed on a Perkin-Elmer TGA7 thermogravimeter in $\mathrm{N}_{2}$ at a heating rate of $2{ }^{\circ} \mathrm{C} / \mathrm{min}$. The IR analyses were performed on samples that were ground to a very small grain size $(\sim 2 \mu \mathrm{m})$, mixed with $\mathrm{KBr}$ in the weight ratio of $0.5 / 360$, and pressed into a $13 \mathrm{~mm}$ diameter pellet using an evacuable die. Care was taken to minimize contact of the $\mathrm{KBr}$ powder or pressed pellets with moisture in the air by keeping the powder at $110^{\circ} \mathrm{C}$ and the pellets in a desiccator. The spectra were collected on a Perkin-Elmer 1600 FTIR instrument with a nominal resolution of $2 \mathrm{~cm}^{-1}$. All spectra were referenced to blank $\mathrm{KBr}$ pellets.

\section{RESULTS}

\section{Individual phases}

Cancrinite was found to have the following optical characteristics: colorless; refractive indices $\varepsilon=1.500$ (2) and $\omega=$ 1.522(2); and parallel extinction. Crystals were generally euhedral or subhedral and developed as short hexagonal bipyramidal prisms (Fig. 1). Unlike the positive correlation between index of refraction and water content for cordierite observed by Medenbach et al. (1980), no obvious correlation was observed 


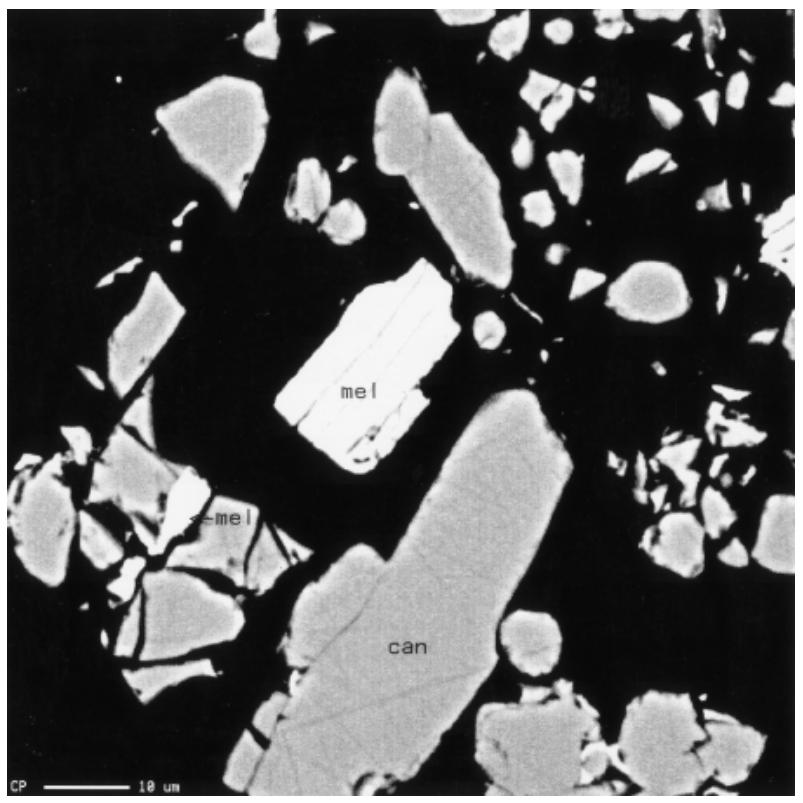

FIGURE 1. Common crystal morphology for synthetic cancrinite and melilite from run 12, Table 3. BSE image; Abbreviations: can = cancrinite, $\mathrm{mel}=$ melilite. Scale bar $=10 \mu \mathrm{m}$.

here. Strong similarities were found between the XRD pattern of the cancrinite formed here and the data listed by Edgar (1963) for the synthetic cancrinite "proper" $\left[3\left(\mathrm{NaAlSiO}_{4}\right) \cdot \mathrm{CaCO}_{3}\right]$. A unit-cell refinement was performed for a cancrinite synthesized at $802(3){ }^{\circ} \mathrm{C}, 1.97(5) \mathrm{kbar}$, and $X_{\mathrm{CO}_{2}}(\mathrm{avg})=0.252(5)$ (40, Table 3) yielding $a=12.607(1) \AA, c=5.120$ (1) $\AA$, and a cell volume of $705 \AA^{3}$, obtained by indexing 31 observed peaks scanned in the $2 \theta$ interval of $19-65^{\circ}$. The refined unit-cell parameters are similar to those listed by Edgar (1963) for synthetic cancrinite “proper": $a=12.59(2) \AA, c=5.17(2) \AA$, and to those given by Hassan and Busseck (1992): $a=12.590$ (3) $\AA, c=5.117$ (1) $\AA$ for natural cancrinite (Bancroft, Ontario) of similar composition: $\mathrm{Na}_{6.0} \mathrm{Ca}_{1.5}\left[\mathrm{Al}_{6} \mathrm{Si}_{6} \mathrm{O}_{24}\right]\left(\mathrm{CO}_{3}\right)_{1.6} \cdot 1.8 \mathrm{H}_{2} \mathrm{O}$. Absorption IR spectra were obtained in the range of $1300-4000 \mathrm{~cm}^{-1}$ and the absorption bands were found to be consistent with the results of previous IR investigations (Flanigen et al. 1971; Moenke 1974; Hermeler et al. 1991; Buhl 1991).

Microprobe analysis of cancrinite (Table 4, Fig. 2) was complicated by the unknown amount of molecular water, carbonate, and possibly hydroxyl. Compositions of synthetic cancrinites, using the microprobe operating conditions described above, essentially approached the composition of ideal cancrinite. The observed $\mathrm{Ca}$ deficiency in most samples (i.e., departure of $\mathrm{Ca}$ from 2 cations per 24 oxygen atoms) could be a consequence of vacancies in the large channel as noticed by Hassan and Busseck (1992) for natural cancrinite from Bancroft, Ontario. The issue of $\mathrm{Na}$ loss during microprobe analysis was assessed independently by using the thermogravimetric (TG) analysis performed on sample can4-1. This sample was heated up to complete melting $\left(1350^{\circ} \mathrm{C}\right)$ and was found to have a total volatile content of $11.19 \mathrm{wt} \%$. The volatile content $\left(\mathrm{CO}_{2}\right.$ and $\mathrm{H}_{2} \mathrm{O}$ ) in this sample as deduced from the total sum from microprobe measurements (avg of 9) was $11.22 \mathrm{wt} \%$, confirm-

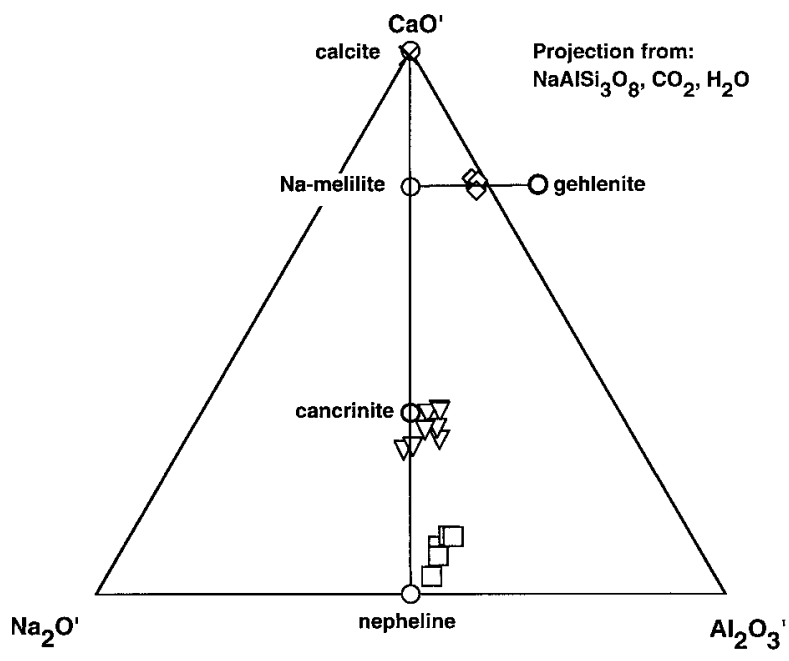

FIGURE 2. Projection of phase compositions from $\mathrm{NaAlSi}_{3} \mathrm{O}_{8}, \mathrm{CO}_{2}$, and $\mathrm{H}_{2} \mathrm{O}$ onto the ternary diagram $\mathrm{Na}_{2} \mathrm{O}-\mathrm{CaO}-\mathrm{Al}_{2} \mathrm{O}_{3}$. Open circles indicate ideal mineral compositions; other symbols are electron microprobe analyses of experimentally produced phases (Table 4): triangles = cancrinite; squares $=$ nepheline; diamonds = melilite; and $\mathrm{X}=$ calcite

ing within analytical error that there was no $\mathrm{Na}$ loss during the microprobe analysis. The complete formula for cancrinite can41 was calculated from information provided by electron microprobe, TG, and IR data (see below).

The synthetic nepheline has $\omega=1.537(2)$ and $\varepsilon=1.534(2)$ with first-order gray interference colors for crystal sizes of 10 $50 \mu \mathrm{m}$ in diameter. Microprobe analyses (Table 4, Fig. 2) show a small uptake of $\mathrm{Ca}$ by nepheline. Chemical zonation was observed via variation in interference colors for large crystals of nepheline (run 65, Table 3).

Calcite was found to be almost omnipresent with a variety of textures. Generally its shape and crystallinity change with the temperature of formation. At lower temperatures $\left(750-850^{\circ} \mathrm{C}\right)$, small rounded or rhombic individual calcite grains are predominate. With increasing temperature, crystals tend to lack defined shapes, appearing mostly as interstitial, fine-grained material in aggregates with nepheline and cancrinite, but also coating the Pt capsule or individual crystals of nepheline or cancrinite, or as large, irregular single crystals. Carbonate precipitation during the quench of the high-temperature charges is inferred from these textures, but it is not clear whether precipitation occurs out of the fluid or out of a carbonate-bearing melt. The $\mathrm{Na}$ content of calcite is $<0.5 \%$ (Table 4, Fig. 2). The optical detection of a clear isotropic glass remains the main evidence used in this study to identify the occurrence of partial melting.

An Na-rich melilite was present as an additional, spontaneously nucleated phase in most of the runs performed at low $\mathrm{CO}_{2}\left(X_{\mathrm{CO}_{2}}=0-0.2\right)$. This synthetic phase lies on the gehlenite $\left(\mathrm{Ca}_{2} \mathrm{Al}_{2} \mathrm{SiO}_{7}\right)$-soda melilite $\left(\mathrm{NaCaAlSi}_{2} \mathrm{O}_{7}\right)$ solid-solution join. The optical properties for melilite are $\omega=1.633(2), \varepsilon=1.631$ (2) and low birefringence (similar to nepheline). The predominant crystal appearance was as short to tabular tetragonal prisms with good basal cleavage (Fig 1). The XRD data for this melilite 
TABLE 4. Electron microprobe analyses of synthetic cancrinite, nepheline, melilite, calcite, and silicate glass

\begin{tabular}{|c|c|c|c|c|c|c|c|c|c|c|c|c|}
\hline Sample & avg & $\mathrm{Na}_{2} \mathrm{O}$ & $\mathrm{Al}_{2} \mathrm{O}_{3}$ & $\mathrm{CaO}$ & $\mathrm{SiO}_{2}$ & Total & $\mathrm{Na}$ & $\mathrm{Al}$ & $\mathrm{Ca}$ & $\mathrm{Si}$ & $\mathrm{Si}+\mathrm{Al}$ & Sum \\
\hline \multicolumn{7}{|c|}{ Cancrinite } & \multicolumn{6}{|c|}{ Cation numbers per $24 \mathrm{O}$ atoms for $\mathrm{Na}, \mathrm{Al}$, and $\mathrm{Si}$} \\
\hline can4-1 & 9 & 17.63 & 29.32 & 7.91 & 33.91 & 88.78 & 6.000 & 6.064 & 1.489 & 6.018 & 12.082 & 19.570 \\
\hline can5-1 & 9 & 17.99 & 28.44 & 7.73 & 33.71 & 87.87 & 6.188 & 5.955 & 1.473 & 5.987 & 11.942 & 19.603 \\
\hline 12 & 14 & 16.45 & 29.38 & 8.66 & 35.05 & 89.55 & 5.540 & 6.025 & 1.615 & 6.096 & 12.121 & 19.277 \\
\hline 53 & 6 & 15.44 & 29.74 & 8.60 & 34.47 & 88.26 & 5.267 & 6.163 & 1.621 & 6.061 & 12.224 & 19.112 \\
\hline 55 & 8 & 14.70 & 28.96 & 9.49 & 33.91 & 87.06 & 5.131 & 6.147 & 1.832 & 6.107 & 12.254 & 19.217 \\
\hline 58 & 11 & 15.14 & 29.73 & 9.89 & 34.79 & 89.55 & 5.144 & 6.149 & 1.860 & 6.102 & 12.251 & 19.255 \\
\hline 62 & 7 & 15.73 & 28.68 & 9.65 & 33.86 & 87.91 & 5.477 & 6.067 & 1.859 & 6.081 & 12.148 & 19.484 \\
\hline 64 & 13 & 14.92 & 28.93 & 7.37 & 33.21 & 84.42 & 5.242 & 6.192 & 1.468 & 6.045 & 12.237 & 18.947 \\
\hline \multicolumn{7}{|c|}{ Nepheline } & \multicolumn{6}{|c|}{ Cations per 40 atoms } \\
\hline can5-1 & 1 & 19.37 & 34.98 & 0.87 & 43.78 & 99.01 & 0.888 & 0.975 & 0.022 & 1.036 & 2.011 & 2.921 \\
\hline 53 & 21 & 18.31 & 33.76 & 1.42 & 44.84 & 98.33 & 0.842 & 0.944 & 0.036 & 1.064 & 2.007 & 2.885 \\
\hline 55 & 20 & 17.92 & 35.82 & 2.65 & 41.47 & 97.86 & 0.835 & 1.014 & 0.068 & 0.996 & 2.011 & 2.914 \\
\hline 58 & 7 & 18.18 & 35.93 & 2.71 & 42.44 & 99.26 & 0.835 & 1.003 & 0.069 & 1.005 & 2.007 & 2.911 \\
\hline 62 & 3 & 17.72 & 35.13 & 2.69 & 41.11 & 96.64 & 0.836 & 1.008 & 0.070 & 1.000 & 2.008 & 2.914 \\
\hline 64 & 7 & 18.99 & 35.74 & 2.33 & 40.93 & 97.99 & 0.887 & 1.015 & 0.060 & 0.986 & 2.002 & 2.950 \\
\hline \multicolumn{7}{|c|}{ Melilite } & \multicolumn{6}{|c|}{ Cations per 70 atoms } \\
\hline can5-1 & 10 & 7.22 & 26.91 & 29.38 & 35.95 & 99.45 & 0.620 & 1.405 & 1.395 & 1.593 & 2.999 & 5.014 \\
\hline can4-1 & 5 & 7.06 & 26.64 & 29.54 & 35.71 & 98.94 & 0.610 & 1.400 & 1.411 & 1.592 & 2.992 & 5.013 \\
\hline 12 & 10 & 7.11 & 24.96 & 27.08 & 36.43 & 95.58 & 0.630 & 1.347 & 1.329 & 1.668 & 3.015 & 4.974 \\
\hline 26 & 8 & 6.58 & 26.58 & 30.66 & 35.28 & 99.10 & 0.571 & 1.399 & 1.467 & 1.575 & 2.974 & 5.011 \\
\hline \multicolumn{7}{|c|}{ Calcite } & \multicolumn{6}{|c|}{ Cations per 10 atom } \\
\hline 55 & 1 & 0.47 & 0.20 & 51.87 & 0.17 & 52.71 & 0.016 & 0.004 & 0.980 & 0.003 & & 1.003 \\
\hline 64 & 1 & 0.41 & 0.17 & 51.94 & 0.19 & 52.71 & 0.014 & 0.004 & 0.981 & 0.003 & & 1.002 \\
\hline
\end{tabular}

were found to be in good agreement with those listed by Louisnathan (1970) for a synthetic soda-melilite and by Edgar (1965) for synthetic gehlenite-soda melilite solid-solutions. The unit-cell parameters for melilite (concentrated from sample can4-1, Table 2) were refined as $a=7.650(1), c=5.046(1) \AA$ and a unit-cell volume of $295 \AA^{3}$, obtained by indexing 16 peaks observed in the $2 \theta$ interval from $17-54^{\circ}$. Using the XRD technique of Edgar (1965), a gehlenite content of $47 \mathrm{wt} \%$ was obtained, similar to the value of $51.5 \mathrm{wt} \%$ based on microprobe analyses (avg of 5) of the same sample. Data from microprobe analyses of different melilite samples are listed in Table 4 and plotted in Figure 2.

\section{Investigation of cancrinite stability in $T-X_{\mathrm{CO} 2}$ space}

The breakdown of cancrinite to nepheline and calcite (reaction 1) was constrained by reversals in the range of $770-950^{\circ} \mathrm{C}$ and $X_{\mathrm{CO}_{2}}$ of $0.8-0.3$ at $2 \mathrm{kbar}$. Starting materials were can2-2, can3-1, and can5-1 (Table 3, Fig. 3). The results are consistent with a simple dehydration boundary in $T-X_{\mathrm{CO}_{2}}$ space (e.g., Kerrick 1974). The consistency of the results and the lack of any extra phases lead to the conclusion that this reaction is indeed a univariant boundary in the four-component system $\mathrm{NaAlSiO}_{4}-\mathrm{CaCO}_{3}-\mathrm{H}_{2} \mathrm{O}-\mathrm{CO}_{2}$ (note compositional degeneracy of the ideal phases in Fig. 2) at constant total pressure. The compositions of cancrinite, nepheline, and calcite, though departing slightly from ideality, are nearly collinear in the projected $\mathrm{CaO}-\mathrm{Na}_{2} \mathrm{O}^{\prime}-\mathrm{Al}_{2} \mathrm{O}_{3}{ }^{\prime}$ system (Fig. 2).

At $X_{\mathrm{CO}_{2}} \sim 0.2$ and $\sim 950{ }^{\circ} \mathrm{C}$ (runs $63,64,65,68$, Table 3 ), the presence of a silicate melt and melilite was detected suggesting that reaction 1 may terminate at an invariant point (point $\mathrm{U}$ in Fig. 3) involving melilite- and liquid-producing reactions. Unfortunately, the exact composition of the liquid phase could not be determined, because heterogeneous quenching occurred in most of the runs, with Ca-rich carbonates coexisting with isotropic silicate glass. A field of coexisting liquid and crystals was contoured based on the identification of the isotropic glass in runs with $X_{\mathrm{CO}_{2}}<0.2$ and on the assumption that the slope of the solidus should be positive in $T-X_{\mathrm{CO}_{2}}$ coordinates in runs with $X_{\mathrm{CO}_{2}}>0.2$ (Fig. 3).

\section{Water content of cancrinite}

We used the IR spectra of the produced cancrinites to quantify their relative water and carbonate contents. The procedure consisted of determining the volatile content of a calibration sample of synthetic cancrinite by TG and using the data to calibrate the area of the $1634 \mathrm{~cm}^{-1}$ IR absorption band for water

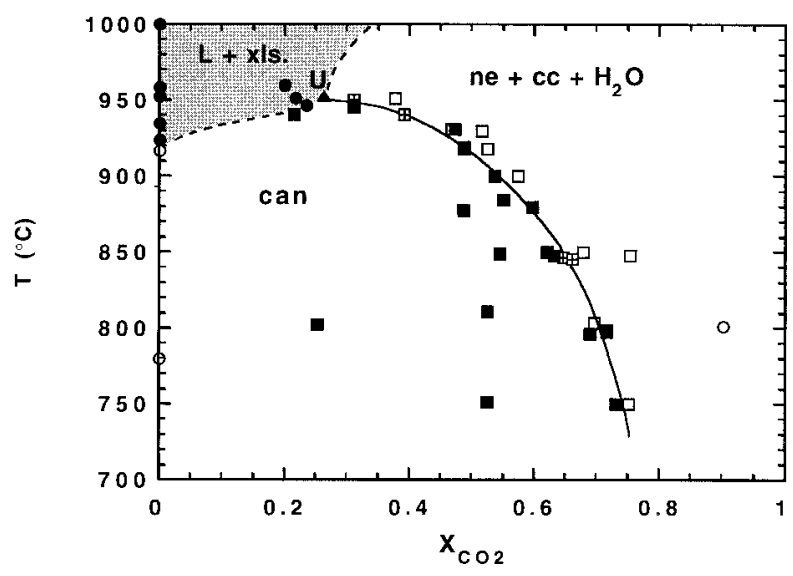

FIGURE 3. Experimental results obtained in this study for reaction 1 in $T-X_{\mathrm{CO}_{2}}$ space. Solid squares $=$ cancrinite growth; open squares $=$ nepheline + calcite growth; crossed open squares $=$ no discernible reaction; open circles $=$ assemblages containing melilite or haüyne in addition to cancrinite, nepheline, and/or calcite; solid circles = assemblages in which presence of silicate melt (L) was detected; $\mathrm{U}=$ invariant point; shaded area $=$ field of liquid and crystals. 
relative to the $1514 \mathrm{~cm}^{-1}$ band for $\mathrm{CO}_{3}^{2-}$. The details of this procedure are discussed below.

One sample of synthetic cancrinite (can4-1, Table 2) was analyzed by TG to determine its water content. TG analyses were performed both by a computer-automated technique, heating over the range of $110-930^{\circ} \mathrm{C}$ at a rate of $2{ }^{\circ} \mathrm{C} / \mathrm{min}$, and by a manual procedure, heating from 110 to $1350^{\circ} \mathrm{C}$ in a stepwise fashion with repeated weighings at each step until a constant weight was reached. The manual procedure was performed over a period of 10 days with an average heating rate of $0.06{ }^{\circ} \mathrm{C} /$ min. The results of these two TG analyses are listed in Table 5 and shown in Figure 4. The two curves are similar in their overall form; however, the mass loss at any given temperature was noticeably less for the automated analysis (curve 1) compared with the manual analysis (curve 2). This discrepancy is ascribed to the faster heating rate of the automated TG process, which did not allow sufficient time for the volatiles to diffuse out of the cancrinite crystals. For quantitative work, we chose the results of the manual TG analysis.

The interpretation of TG analysis was based on results of a similar study (Hassan 1996) and reconfirmed by our IR analysis. The TG analyses of can4-1 were interpreted as follows. A total of $5.09( \pm 0.04) \mathrm{wt} \%$ loss at $785^{\circ} \mathrm{C}$ was assigned to the release of water molecules ("zeolitic" water), whereas the remaining weight loss of $\sim 6.10 \mathrm{wt} \%$ occurring up to the temperature of complete melting $\left(\sim 1350{ }^{\circ} \mathrm{C}\right)$ was assigned to the release of $\mathrm{CO}_{2}$ and of hydroxyl groups. Optical and XRD analysis of the heated material confirmed that cancrinite was stable up to at least $785^{\circ} \mathrm{C}$ and that it decomposed to a mixture of nepheline + haüyne above $880{ }^{\circ} \mathrm{C}$. Combining the observed mass losses from the TG analysis with the electron microprobe analysis of sample can4-1 yields $3.09( \pm 0.04)$ moles of $\mathrm{H}_{2} \mathrm{O}$ per mole of cancrinite, leading to the chemical formula $\mathrm{Na}_{6.00} \mathrm{Ca}_{1.49}\left[\mathrm{Al}_{6.06} \mathrm{Si}_{5.95} \mathrm{O}_{24}\right]\left(\mathrm{CO}_{3}\right)_{1.45}(\mathrm{OH})_{0.08} \cdot 3.09 \mathrm{H}_{2} \mathrm{O}$. If one assumes that the framework portion of cancrinite has the ideal formula of $6 \mathrm{Nepheline} \cdot 2 \mathrm{CaCO}_{3}$ (see Fig. 2), about the same zeolitic water content, i.e., $3.13( \pm 0.04)$ moles of $\mathrm{H}_{2} \mathrm{O}$ is obtained, within the limits of analytical error. Notice that the mass loss in the range of $785-1350{ }^{\circ} \mathrm{C}$ observed in the TG analysis is essentially all $\mathrm{CO}_{2}$, assigned to $\mathrm{Ca}$ as the carbonate anion, with only a very small amount of hydroxyl anion needed to account for the charge balance. The existence of hydroxyl groups is documented by the presence of appropiate absorbtion bands in the IR spectrum of the cancrinite.

Portions of the cancrinite (can4-1) were preserved at various stages of TG analysis for IR analysis. Qualitatively, the IR spectra of the thermally treated cancrinite samples were consistent with TG results, in that the peak and broad band of the molecular water (found at $1634 \mathrm{~cm}^{-1}$ and between 3400-3620 $\mathrm{cm}^{-1}$, respectively) gradually decreased and disappeared completely above $630{ }^{\circ} \mathrm{C}$, whereas $\mathrm{CO}_{3}^{2-}$ peaks at about 1400 and $1514 \mathrm{~cm}^{-1}$ remained unchanged up to $880{ }^{\circ} \mathrm{C}$ (Fig. 5). In multi-phase samples, i.e., run products, the intense $1420 \mathrm{~cm}^{-1}$ $\mathrm{CO}_{3}^{2-}$ vibration of calcite was found to interfere with the 1400 $\mathrm{cm}^{-1} \mathrm{CO}_{3}^{2-}$ peak of cancrinite. In several cases, the broad band of water with the two hydroxyl peaks, in the region 3400-3620 $\mathrm{cm}^{-1}$, was strongly distorted or of very low intensity, especially for cancrinites equilibrated in the presence of high $X_{\mathrm{CO}_{2}}$. The non-interfering IR peaks that could be used in a quantitative analysis of the water content of cancrinite were the $\mathrm{H}_{2} \mathrm{O}$ peak at $1634 \mathrm{~cm}^{-1}$ and the $\mathrm{CO}_{3}^{2-}$ peak at $1514 \mathrm{~cm}^{-1}$. Determination of the water content by measurement of the absolute intensities of the absorption bands requires strict control of instrument and sample parameters (e.g., absorption pathlength, sample to $\mathrm{KBr}$ ratio, particle size, etc.), which is not easily done when using our pressed-pellet technique. If the carbonate content of the cancrinite samples is assumed to be constant, then we can determine the water content by referencing the area of the $\mathrm{H}_{2} \mathrm{O}$ peak at $1634 \mathrm{~cm}^{-1}$ to the $\mathrm{CO}_{3}^{2-}$ peak at $1514 \mathrm{~cm}^{-1}$. The assumption of constant carbonate content of the calibration cancrinites up to $540{ }^{\circ} \mathrm{C}$ (listed in Table 5) and of the unknown cancrinites (listed in Table 3) was based on (1) the relatively constant intensity of the $\mathrm{CO}_{3}^{2-}$ peak compared to the cancrinite T-O asymmetric stretch at about $1000 \mathrm{~cm}^{-1}$ (for samples lacking nepheline) and (2) the retention of $\mathrm{CO}_{2}$ up to temperatures of $730-880^{\circ} \mathrm{C}$ (at $\left.1 \mathrm{~atm}\right)$ for synthetic cancrinite similar to that studied here (Buhl 1991) and even up to $920-950{ }^{\circ} \mathrm{C}$ as reported by Hassan (1996). The technique known as linear reduction, which involves the integration of the peak area for the

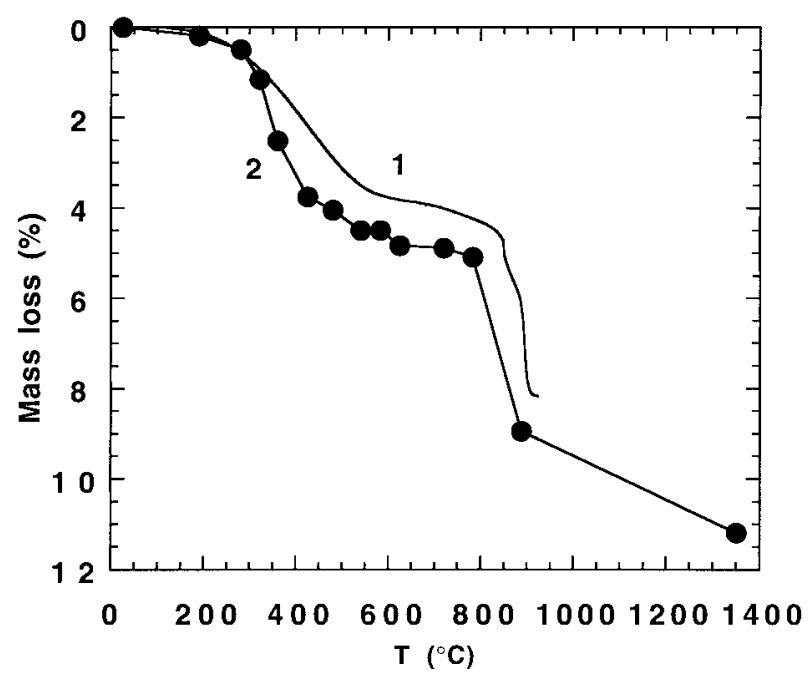

FigURE 4. TGA results for sample can4-1. Curve 1 was obtained by a computer-automated procedure whereas curve 2 was obtained by a manual stepwise heating with repeated weighing at each step (open circles) until constant mass was established. Heating rate for curve 1 is $2{ }^{\circ} \mathrm{C} / \mathrm{min}$ whereas that for curve 2 is $0.06^{\circ} \mathrm{C} / \mathrm{min}$.

TABLE 5. TGA results for sample can4-1

\begin{tabular}{lcccc}
\hline \hline $\begin{array}{l}\text { Heating rate } \\
\left({ }^{\circ} \mathrm{C} / \mathrm{min}\right)\end{array}$ & Sample code & $T,{ }^{\circ} \mathrm{C}$ & $\begin{array}{c}\text { Total mass } \\
\text { loss }(\mathrm{wt} \%)\end{array}$ & $\mathrm{n}_{\mathrm{H}_{2} \mathrm{O}}$ \\
\hline 0.06 (manual) & ca1 & 110 & 0.00 & 3.09 \\
& ca2 & 320 & 1.16 & 2.38 \\
& ca3 & 420 & 3.76 & 0.81 \\
& ca4 & 540 & 4.50 & 0.34 \\
& & & & \\
2 (automated) & can1 & 110 & 0.00 & 3.09 \\
& can2 & 250 & 0.37 & 2.86 \\
& can3 & 300 & 0.75 & 2.64 \\
& can4 & 350 & 1.23 & 2.34 \\
& can5 & 420 & 2.06 & 1.84 \\
& can6 & 470 & 2.69 & 1.46 \\
\hline
\end{tabular}



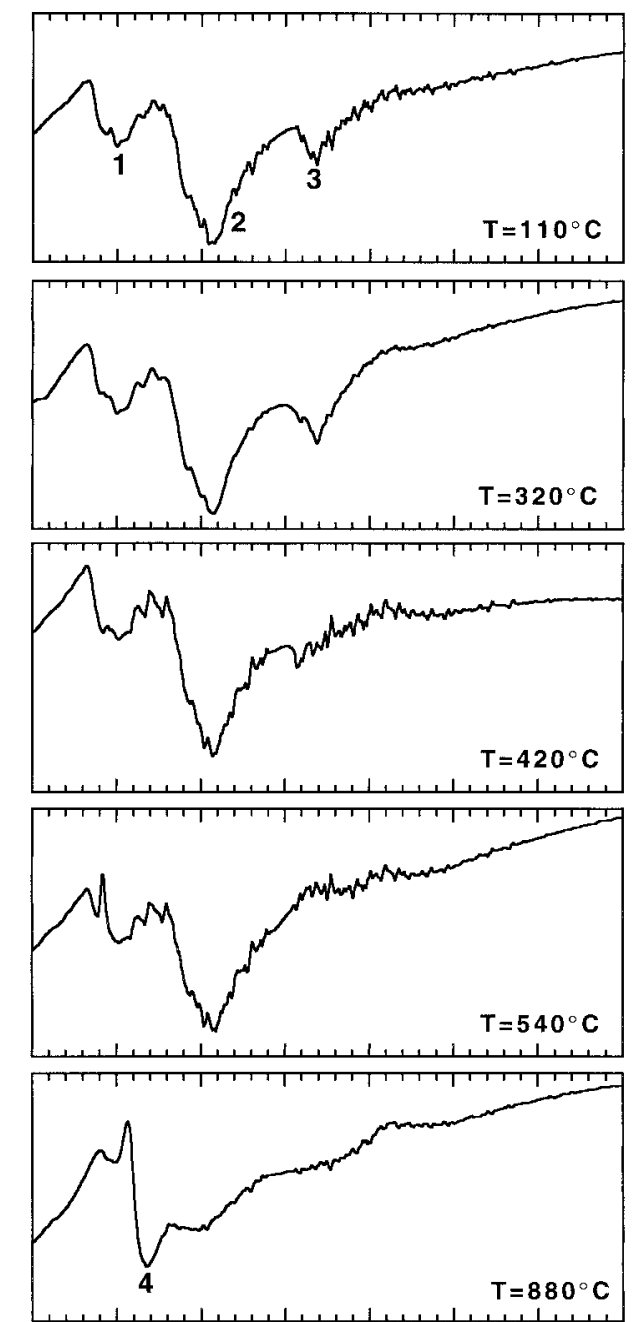

13001400150016001700180019002000 wavenumber $\left(\mathrm{cm}^{-1}\right)$

FigURE 5. Transmission IR spectra for portions of sample can4-1 heated at successively higher temperatures. Numbers indicate key absorption bands: $1=$ cancrinite $\mathrm{CO}_{3}^{2-}$ band at $1400 \mathrm{~cm}^{-1} ; 2=$ cancrinite $\mathrm{CO}_{3}^{2-}$ band at $1514 \mathrm{~cm}^{-1} ; 3=$ cancrinite $\mathrm{H}_{2} \mathrm{O}$ band at $1634 \mathrm{~cm}^{-1}$; and 4 = calcite $\mathrm{CO}_{3}^{2-}$ band at $1420 \mathrm{~cm}^{-1}$ resulted from the breakdown of cancrinite.

$\mathrm{H}_{2} \mathrm{O}$ absorption band between $1600-1689 \mathrm{~cm}^{-1}$ (tangent background) and normalization to the intensity of the $\mathrm{CO}_{3}^{2-}$ peak at $1514 \mathrm{~cm}^{-1}$, was applied to the IR spectra. Application of this method to the two sets of TG data in Table 5 yielded the calibration curve shown in Figure 6, which conforms to a straight line with a correlation coefficient of 0.92 and a standard error of $\pm 0.4 \mathrm{n}_{\mathrm{H}_{2} \mathrm{O}}$.

The above procedure was applied to 16 runs listed in Table 3 and the resultant water contents of the cancrinite are listed in Table 6 and shown in Figure 7. Figure 7a shows a plot of $n_{\mathrm{H}_{2} \mathrm{O}}$ vs. temperature for experiments performed at an approximately constant $X_{\mathrm{CO}_{2}}$ of 0.5 where it can be seen that the water content decreases with increasing $T$. Figure $7 \mathrm{~b}$ shows the values of $\mathrm{n}_{\mathrm{H}_{2} \mathrm{O}}$ of cancrinites plotted in $T-X_{\mathrm{CO}_{2}}$ space. In general, cancrinite has a higher water content at lower temperatures and higher $X_{\mathrm{H}_{2} \mathrm{O}}$ values. Two samples have anomalous values (shown in parentheses, Fig. 7b) and two other samples with almost identical location in $T-X_{\mathrm{CO}_{2}}$ space have a difference in $\mathrm{n}_{\mathrm{H}_{2} \mathrm{O}}$ of about 0.6 , similar to the water content calibration error of \pm 0.4 . Although there is certainly no theoretical reason why the water content of cancrinite should be constant along its stability boundary, it is a simple empirical observation that the water content is essentially constant within the analytical precision of our technique (Fig. 7b). Ten experimental points (Table 6), those lying closest to the stability boundary and with $\mathrm{n}_{\mathrm{H}_{2} \mathrm{O}}$ ranging from 0.7 to 1.4 , give an average of $\mathrm{n}_{\mathrm{H}_{2} \mathrm{O}}$ eq $=1.1$ with an estimated error of \pm 0.4 for cancrinite at the boundary.

\section{Thermodynamic analysis}

The purpose of the thermodynamic analysis was to demonstrate the internal consistency of the univariant boundary for reaction 1 balanced for $1.1 \mathrm{H}_{2} \mathrm{O}$ :

$$
\begin{array}{r}
\mathrm{Na}_{6} \mathrm{Ca}_{1.5}\left[\mathrm{Al}_{6} \mathrm{Si}_{6} \mathrm{O}_{24}\right]\left(\mathrm{CO}_{3}\right)_{1.5} \cdot 1.1 \mathrm{H}_{2} \mathrm{O}= \\
\text { can } \\
= \\
6 \mathrm{NaAlSiO}_{4}+1.5 \mathrm{CaCO}_{3}+1.1 \mathrm{H}_{2} \mathrm{O} \\
\mathrm{ne}+\text { cc }+ \text { fluid }
\end{array}
$$

and to extract the third-law entropy and enthalpy of formation for cancrinite. Under the conditions of equilibrium, one must have:

$$
\begin{aligned}
& \Delta G_{P T}=0=\Delta H^{0}-T\left(\Delta S^{0}\right)+ \\
& \int_{T_{0}}^{T} \Delta C_{P} \mathrm{~d} T-T \int_{T_{0}}^{T}\left(\Delta C_{P} / T\right) \mathrm{d} T+ \\
& \int_{P_{0}}^{P} \Delta V_{\text {solids }}^{0} \mathrm{~d} P+\mathrm{n}_{\mathrm{H}_{2} \mathrm{O}} \mathrm{R} T \ln f_{\mathrm{H}_{2} \mathrm{O}}^{P T}+ \\
& \mathrm{R} T \ln \mathrm{K}_{\mathrm{a}}
\end{aligned}
$$

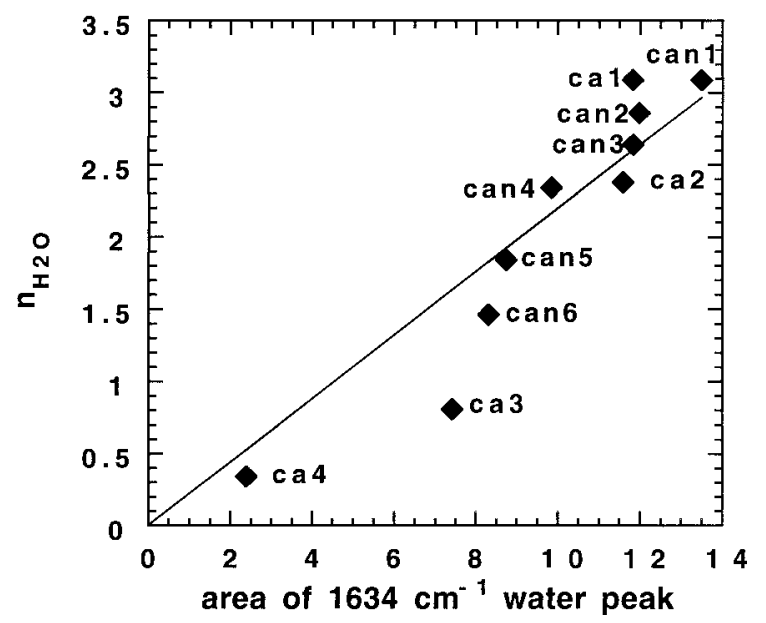

FIGURE 6. Calibration line for determining the water content of synthetic cancrinite formed in this study using the IR absorption band of molecular water at $1634 \mathrm{~cm}^{-1}$ relative to the carbonate band at 1514 $\mathrm{cm}^{-1}$, as discussed in text. Regression line was forced through the origin. Samples can1-can6 and ca1-ca4 are listed in Table 5. 

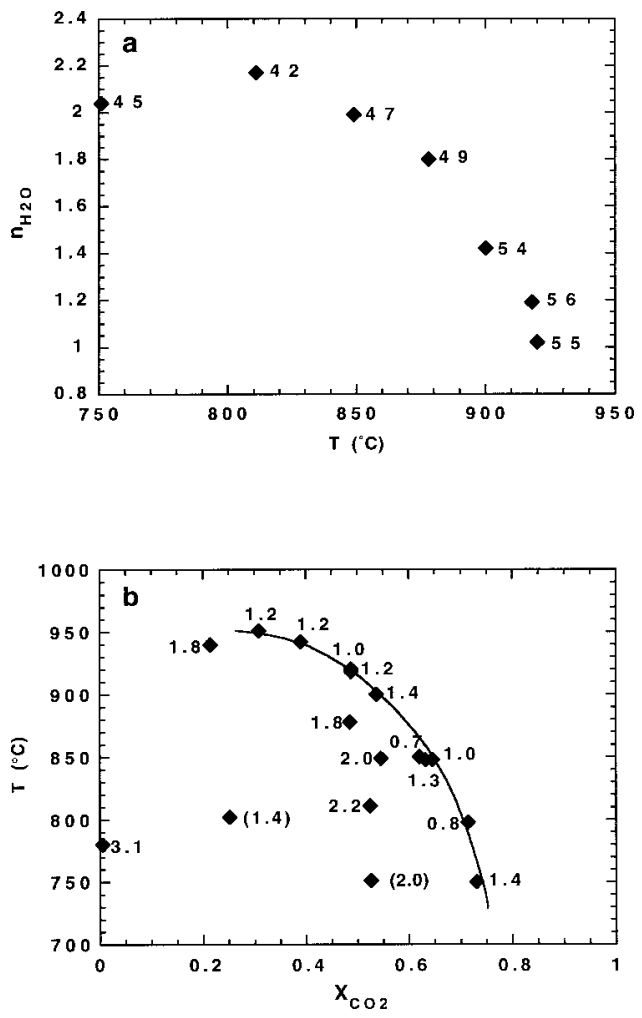

FiguRE 7. (a) Variation of the water content of cancrinite with temperature for experiments performed at an approximately constant $X_{\mathrm{CO}_{2}}$ value of 0.5 . Numbers represent run codes, listed in Table 3. (b) Variation of the water content of cancrinite in $T-X_{\mathrm{CO}_{2}}$ space. Solid diamonds are individual cancrinite-bearing experiments labeled with the number of moles of water per 24 oxygen atoms tied to $\mathrm{Na}, \mathrm{Al}$, and $\mathrm{Si}$. The curve represents the univariant boundary (reaction 1). Within the limitations given by the resolution of TG-IR technique, cancrinite water content along the univariant boundary appears to be constant at $\mathrm{n}_{\mathrm{H}_{2} \mathrm{O}}=1.1 \pm 0.4$ moles.

where $\Delta G, \Delta H, \Delta S, \Delta C_{P}$, and $\Delta V$ are the Gibbs free energy, enthalpy, entropy, heat capacity, and volume change of reaction, respectively, $\mathrm{n}_{\mathrm{H}_{2} \mathrm{O}}$ is the molar coefficient of water, $f^{P T}$ is the fugacity of water at the pressure $(P)$ and temperature $(T)$ of interest, and $\mathrm{K}_{\mathrm{a}}$ is the equilibrium constant. The standard state is that of unit activity for the pure solids at the pressure and temperature of interest, the ideal gas at one bar and temperature of interest for water. Values at the reference temperature $\left(T_{0}=298 \mathrm{~K}\right)$ and pressure $\left(P_{0}=1 \mathrm{bar}\right)$ are indicated by a superscript zero. In this study, neither the heat-capacity expressions, thermal expansivities, nor compressibilities of cancrinite are known, so the $\Delta C_{P}$ terms in reaction 3 were set to zero and the value of $\Delta V$ was assumed to be independent of temperature. Cancrinite of a specific water content and calcite was assumed to be pure phases. However, the significant $\mathrm{Ca}$ content of nepheline (Table 4) was accounted for by assuming an ideal solution between nepheline and hexagonal anorthite, so that the equilibrium constant was calculated as:

$$
\mathrm{K}_{\mathrm{a}}=\left(a_{\mathrm{H}_{2} \mathrm{O}}^{\text {fluid }}\right)^{n_{\mathrm{H}_{2} \mathrm{O}}}\left(a_{\mathrm{NaAlSiO}_{4}}^{\text {nepheline }}\right)^{n_{\text {neppheine }}}
$$

TABLE 6. Cancrinite water content from IR analysis

\begin{tabular}{|c|c|c|c|}
\hline Sample code & $T,{ }^{\circ} \mathrm{C}$ & $X_{\mathrm{CO}_{2}}{ }^{*}$ & $\mathrm{n}_{\mathrm{H}_{2} \mathrm{O}}$ \\
\hline 40 & 802 & 0.25 & 1.4 \\
\hline 42 & 811 & 0.53 & 2.1 \\
\hline $44 \dagger$ & 750 & 0.73 & 1.4 \\
\hline 45 & 751 & 0.53 & 2.0 \\
\hline $46 \dagger$ & 850 & 0.62 & 0.7 \\
\hline 47 & 849 & 0.55 & 2.0 \\
\hline 49 & 878 & 0.49 & 1.8 \\
\hline $54 \dagger$ & 900 & 0.54 & 1.4 \\
\hline $55 \dagger$ & 920 & 0.49 & 1.0 \\
\hline $56 \dagger$ & 918 & 0.49 & 1.2 \\
\hline $62 \dagger$ & 942 & 0.39 & 1.2 \\
\hline 64 & 940 & 0.22 & 1.8 \\
\hline $67 \dagger$ & 951 & 0.31 & 1.2 \\
\hline $69 \dagger$ & 848 & 0.65 & 1.0 \\
\hline $70 \dagger$ & 848 & 0.63 & 1.3 \\
\hline $74 \dagger$ & 799 & 0.72 & 0.8 \\
\hline
\end{tabular}

Incorporating the above assumptions, one can rearrange Equation 3 as follows:

$$
H^{\prime}=-\Delta H^{0}+T \Delta S^{0}=\Delta V_{\text {soius }}^{0}\left(P-P_{0}\right)+\mathrm{n}_{\mathrm{H}_{2} \mathrm{O}} \mathrm{R} T \ln f_{\mathrm{H}_{2} \mathrm{O}}^{P T}+\mathrm{R} T \ln \mathrm{K}_{\mathrm{a}}
$$

so that a plot of $H^{\prime}$ vs. T yields a straight line with an intercept of $-\Delta \mathrm{H}^{0}$ and a slope of $\Delta S^{0}$

Thermodynamic data for nepheline, calcite, and water were taken from Holland and Powell (1998) and the $\mathrm{R} T \ln f_{\mathrm{H}_{2} \mathrm{O}}$ data were taken from the polynomial expression given by Powell and Holland (1985). For the relatively high temperatures used in this study $\left(750-960^{\circ} \mathrm{C}\right)$, it was assumed that the fluid is an ideal mixture of $\mathrm{H}_{2} \mathrm{O}$ and $\mathrm{CO}_{2}$, so that $a_{\mathrm{H}_{2} \mathrm{O}}=X_{\mathrm{H}_{2} \mathrm{O}}=1-X_{\mathrm{CO}_{2}}$. The nepheline activity is $a_{\text {neph }}=X_{\text {neph }}=0.88$ (average of $59 \mathrm{mi}$ croprobe analyses). The molar volume of cancrinite is 424.62 $\mathrm{cm}^{3} / \mathrm{mol}$, as determined in this study for can4-1.

The determination of $H^{\prime}$ was performed using twenty experimental results that fall in the vicinity of the univariant boundary, e.g., with little or no evidence of reaction. Three different $\mathrm{n}_{\mathrm{H}_{2} \mathrm{O}}$ values of $0.7,1.1$, and 1.5 were chosen to reflect the \pm 0.4 error on the determination of $\mathrm{n}_{\mathrm{H}_{2} \mathrm{O}}$. The resultant $\mathrm{H}^{\prime}$ vs. $\mathrm{T}$ regressions are shown in Figure 8. The excellent correlation coefficient $(r=0.993)$ supports the thermodynamic consistency of the experimental data for reaction 2 and the assumption that the water content of cancrinite along the univariant boundary does not change. For the case of $\mathrm{n}_{\mathrm{H}_{2} \mathrm{O}}=1.1$, the straight-line fit gives $\Delta H^{0}$ of reaction of $74.5 \pm 3.5 \mathrm{~kJ}$ and $\Delta S^{0}$ of reaction of $111.4 \pm 3.1 \mathrm{~J} / \mathrm{K}$. Assumption of an uncertainty of \pm 0.4 in $\mathrm{n}_{\mathrm{H}_{2} \mathrm{O}}$ leads to errors for $\Delta H^{0}$ and $\Delta S^{0}$ of reaction of $\pm 24 \mathrm{~kJ}$ and \pm 43 $\mathrm{J} / \mathrm{K}$, respectively. The thermochemical properties of cancrinite can be extracted from the relationships:

$$
\Delta H_{\mathrm{fcan}}^{0}\left(\mathrm{n}_{\mathrm{H}_{2} \mathrm{O}}=1.1\right)=-\Delta H_{r}^{0}+6 \Delta H_{\mathrm{ffe}}^{0}+1.5 \Delta H_{\mathrm{fcc}}^{0}+1.1 \Delta H_{\text {fsteam }}^{0}
$$

$S_{\text {can }}^{0}\left(\mathrm{n}_{\mathrm{H}_{2} \mathrm{O}}=1.1\right)=-\Delta S_{r}^{0}+6 S_{\mathrm{ne}}^{0}+1.5 S_{\mathrm{cc}}^{0}+1.1 S_{\mathrm{steam}}^{0}$ 


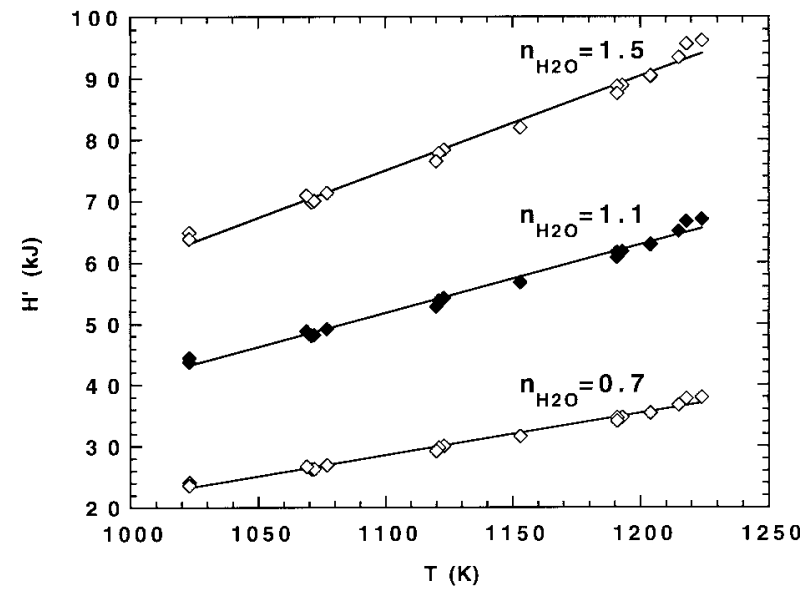

Figure 8. $\mathrm{H}^{\prime}$ vs. $T$ plot for 17 experimental data (listed in Table 3) along the univariant boundary of reaction 1 for the case of $n_{\mathrm{H}_{2} \mathrm{O}}$ per cancrinite formula being 1.1 (solid diamonds) \pm 0.4 (open diamonds). The linear regressions to these three lines are: $\mathrm{H}^{\prime}\left(\mathrm{n}_{\mathrm{H}_{2} \mathrm{O}}=1.5\right)=-98.4+$ $0.154 \cdot T, \mathrm{H}^{\prime}\left(\mathrm{n}_{\mathrm{H}_{2} \mathrm{O}}=1.1\right)=-74.5+0.111 \cdot T$, and $\mathrm{H}^{\prime}\left(\mathrm{n}_{\mathrm{H}_{2} \mathrm{O}}=0.7\right)=-50.6+$ $0.068 \cdot T$, where the slope is $\Delta S^{0}$ of reaction (in $\mathrm{kJ} / T$ ) and the intercept is $-\Delta H^{0}$ of reaction (in $\mathrm{kJ}$ ), respectively.

From Equations 6 one obtains $\mathrm{DH}_{f \text { can }}^{0}\left(\mathrm{n}_{\mathrm{H} 2 \mathrm{O}}=1.1\right)$ of -14722 $\pm 147 \mathrm{~kJ}$ and $S_{\text {can }}^{0}\left(\mathrm{n}_{\mathrm{H} 2 \mathrm{O}}=1.1\right)$ of $981 \pm 118 \mathrm{~J} / \mathrm{K}$, where the uncertainty in the water content of cancrinite is the dominant source of error.

\section{ACKNOWLEDGMENTS}

We are indebted to E.J. Essene, R.C. Newton, and P.I. Nabelek for thorough reviews of this paper. We thank T.K. Lowenstein for the use of the microscopy lab and W.H. Blackburn for assistance with the electron microprobe analyses. Special thanks are given to the Department of Chemistry at Binghamton University for facilitating the access to the IR and TG techniques. This research was supported by NSF grant no. EAR-9316079 to D.M.J.

\section{REFERENCES CITED}

Appleman, D.E. and Evans, H.J. Jr. (1973) Job 9214: Indexing and least-squares refinement of powder diffraction data. U.S. National, Technical Information Service, PB-216, 188.

Barrer, R.M., Cole, J.F., and Villiger, H. (1970) Syntheses, properties, and crystal structure of salt filled cancrinites. In Chemistry of Soil Minerals, VIII, Journal of the Chemical Society of London, A, 1523-1531.

Belokoneva, E.L., Uvarova, T.G., and Dem'yanets, L.N. (1985) Crystal structure of synthetic Ge-cancrinite $\mathrm{Na}_{8}\left[\mathrm{Al}_{6} \mathrm{Ge}_{6} \mathrm{O}_{24}\right] \mathrm{Ge}(\mathrm{OH})_{6} \cdot 2 \mathrm{H}_{2} \mathrm{O}$. Soviet Physics Crystallography, 31, 874-878.

Bresciani Pahor, N., Calligaris, M., and Randaccio, L. (1982) Structure of basic cancrinite. Acta Crystallographica, B38, 893-895.

Buhl, J.C. (1991) Synthesis and characterization of the basic and non-basic members of the cancrinite-natrodavyne family. Thermochimica Acta, 178, 19-31.

Constantinescu, E. and Anastasiu, N. (1979) Nepheline du massif de Ditrau. Analele Universitatii Bucuresti, Geologie, 28, 15-27.

Deer, W.A., Howie, R.A., and Zussman, J. (1963) Rock-Forming Minerals, Vol. 4. Wiley, New York.

Edgar, A.D. (1963) Studies on cancrinites: II. Stability fields and cell dimensions of calcium and potassium-rich cancrinites. Canadian Mineralogist, 8, 53-67.

(1965) Lattice parameters of melilite solid solutions and a reconnaissance of phase relations in the system $\mathrm{Ca}_{2} \mathrm{Al}_{2} \mathrm{SiO}_{7}$ (gehlenite) $-\mathrm{Ca}_{2} \mathrm{MgSi}_{2} \mathrm{O}_{7}$ (akermanite)- $\mathrm{NaCaAlSi}_{2} \mathrm{O}_{7}$ (soda-melilite) at $1000 \mathrm{~kg} / \mathrm{cm}^{2}$ water vapor pressure. Canadian Journal of Earth Science, 2, 596-623.

Edgar, A.D. and Burley, B.J. (1963) Studies on cancrinites I-Polymorphism in sodium carbonate rich cancrinite-natrodavyne. Canadian Mineralogist, 7, 631642 .

Eitel, W. (1922) Über das system $\mathrm{CaCO}_{3}-\mathrm{NaAlSiO}_{4}$ (Calcit-Nephelin) und den Cancrinit. Neues Jahrbuch für Mineralogie, 2, 45-61.

(1954) The Physical Chemistry of the Silicates. University of Chicago Press, Illinois.
Emiraliev, A. and Yamzin, I.I. (1982) Neutron-diffraction refinement of the structure of carbonate-cancrinite. Soviet Physics Crystallography, 27, 27-30.

Fein, J.B. and Walther, J.V. (1987) Calcite solubility in supercritical $\mathrm{CO}_{2}-\mathrm{H}_{2} \mathrm{O}$ fluids. Geochimica et Cosmichimica Acta, 51, 1665-1673.

Flanigen, E.M., Khatami, H., and Szymanski, H.A. (1971) Infrared structural studies of zeolite frameworks. Advances in Chemistry Series, 101, 201-229.

Grundy, H.D. and Hassan, I. (1982) The crystal structure of carbonate rich cancrinite. Canadian Mineralogist, 20, 239-251.

Hamilton, D.L. (1961) Nephelines as crystallization temperature indicators. Journal of Geology, 69, 321-329.

Hassan, I. (1996) The thermal behavior of cancrinite. Canadian Mineralogist, 34, 893-900.

Hassan, I. and Buseck, P.R. (1992) The origin of the superstructure and modulations in cancrinite. Canadian Mineralogist, 30, 49-59.

Hassan, I. and Grundy, H.D. (1991) The crystal structure of basic cancrinite, ideally $\mathrm{Na}_{8}\left[\mathrm{Al}_{6} \mathrm{Si}_{6} \mathrm{O}_{24}\right](\mathrm{OH})_{2} \cdot 3 \mathrm{H}_{2} \mathrm{O}$. Canadian Mineralogist, 29, 377-383.

Henderson, C.M.B. and Ezepue M.J. (1989) Marandguzi alkaline complex, Zimbabue. In C. Leelanandam Ed., Alkaline rocks. Geological Society of India Memoirs, 15, Bangalore.

Henderson, C.M.B. and Roux, J. (1977) Inversions in sub-potassic nephelines. Contributions to Mineralogy and Petrology, 61, 279-298.

Hermeler, G., Buhl, J.-Ch., and Hoffman, W. (1991) The influence of carbonate on the synthesis of an intermediate phase between sodalite and cancrinite. Catalysis Today, 8, 415-426.

Holland, T.J.B. and Powell, R. (1998) An internally consistent thermodynamic data set for phases of petrological interest. Journal of Metamorphic Geology, 16, 309-343.

Holloway, J.R. (1971) Internally heated pressure vessels. In G.C. Ulmer, Ed., Research techniques for high pressure and high temperature, p. 217-258. Springer Verlag, Berlin.

Jarchow, O. (1965) Atomanordnung und Strukturverfeinerung von Cancrinit. Zeitschrift für Kristallographie, 122, 407-422.

Jenkins, D.M. and Clare, A.K. (1990) Comparison of the high-temperature and high-pressure stability limits of synthtic and natural tremolite. American Mineralogist, 75, 358-366.

Kerrick, D.M. (1974) Review of metamorphic mixed-volatile $\left(\mathrm{H}_{2} \mathrm{O}-\mathrm{CO}_{2}\right)$ equilibria. American Mineralogist, 59, 729-762.

Klaska R., Klaska, K.-H., and Jarchow, O. (1979) Strukturelle Ergebnisse zu Hydrothermalsynthesen von Tetraedergeruststrukturen $\mathrm{M}^{\mathrm{p}} \mathrm{X}_{\mathrm{p}} \mathrm{Y}_{\mathrm{p}(1+\mathrm{n})} \mathrm{O}_{4 \mathrm{p}+2 \mathrm{n}}$. Soviet Physics Crystallography, 149, 137.

Liu, C., Li S., Tu, K., and Xu, R. (1993) Synthesis of cancrinite in a butane-1,3-diol system. Journal of the Chemical Society, Chemical Communications, 16451646.

Louisnathan, D. (1970) The crystal structure of synthetic soda melilite, $\mathrm{CaNaAlSi}_{2} \mathrm{O}_{7}$, Zeitschrift fuer Kristallographie, 131, 314-321.

Medenbach, O., Maresch, W.V., Mirwald, W., and Schreyer, W., (1980) Variation of refractive index of synthetic $\mathrm{Mg}$-cordierite with $\mathrm{H}_{2} \mathrm{O}$ content. American Mineralogist, 65, 367-373.

Moenke, H.H.W. (1974) Silica, the three-dimensional silicates, borosilicates and beryllium silicates. In V.C. Farmer, Ed., The Infrared Spectra of Minerals. Mineralogical Society Monograph, London.

Morgan, G.B., VI, and London, D. (1996) Optimizing the electron microprobe analysis of hydrous alkali aluminosilicate glasses. American Mineralogist, 81, 11761185 .

Nadezhina, T.N., Rastsvetaeva, R.K., Pobedimskaya, E.A., and Khomyakov, A.P. (1991) Crystal structure of natural hydroxyl-containing cancrinite. Soviet Physics Crystallography, 36, 325-327.

Nithollon, P. (1955) Structure cristalline de la cancrinite. Publications scientifiques et techniques du ministère de l'air, France, Notes Techniques, 53, 48 pp.

Phoenix, R. and Nuffield, E.W. (1949) Cancrinite from Blue Mountain, Ontario. American Mineralogist, 24, 452-455.

Powell, R. and Holland, T.J.B. (1985) An internally consistent thermodynamic dataset with uncertainties and correlations: 1 . Methods and worked example. Journal of Metamorphic Geology, 3, 327-342.

Pulfrey, W. (1949) Ijolitic rocks near Homa Bay, western Kenya. Quarterly Journal of the Geological Society, 105, 425-459.

Smolin, Y.I., Shepelev, Y.F., Butikova, I.K., and Kobyakov, I.B. (1981) Crystal structure of cancrinite. Soviet Physics Crystallography, 26, 33-35.

Sobolev, V.S., Bazarova, T.Y., and Kostyuk, V.P. (1974) Inclusions in the minerals of some types of alkaline rocks. In H. Sorensen, Ed., The Alkaline Rocks. p. 389401. Wiley, New York.

Watkinson, D.H. (1965) Melting relationships in parts of the system $\mathrm{N}_{2} \mathrm{O}-\mathrm{K}_{2} \mathrm{O}-\mathrm{CaO}-\mathrm{Al}_{2} \mathrm{O}_{3}-\mathrm{SiO}_{2}-\mathrm{CO}_{2}-\mathrm{H}_{2} \mathrm{O}$ with applications to carbonate and alkalic rocks. PhD Thesis, The Pennsylvania State University.

Watkinson, D.H. and Wyllie, P.J. (1971) Experimental study of the composition join $\mathrm{NaAlSiO}_{4}-\mathrm{CaCO}_{3}-\mathrm{H}_{2} \mathrm{O}$ and the genesis of alkalic rock-carbonatite complexes. Journal of Petrology, 12, 357-378.

MANUSCRIPT RECEIVED MAY 28, 1998

MANUSCRIPT ACCEPTED JULY 19, 1999

PAPER HANDLED BY CRAIG MANNING 